\title{
Constitutional Limitations on State- Enacted Bankruptcy Exemption Legislation and the Long Overdue Case for Uniformity
}

\author{
by \\ Lawrence Ponoroff*
}

\section{INTRODUCTION}

The past few decades have witnessed numerous attempts to supply a theoretical justification for the consumer bankruptcy system, ranging from considerations of procedural convenience (or inconvenience), to assuring prudent credit decision-making, to the accomplishment of unique objectives of social and distributive justice. ${ }^{1}$ Whatever the explanation, however, the un-

*Samuel M. Fegtly Chair in Commercial Law, The University of Arizona James E. Rogers College of Law. I'd like to express my appreciation to my friend and frequent collaborator, Professor Markell, formerly Judge Markell, and even more formerly, "Bruce," whose dissenting opinion in Sticka v. Applebaum (In re Applebaum), 422 B.R. 684, 694 (B.A.P. 9th Cir. 2009), got me thinking about this topic. That said, any errors are, sadly, my own and not his.

${ }^{1}$ See, e.g., John M.Czarnetzky, The Individual and Failure: A Theory of the Bankruptcy Discharge, 32 ARrz. ST. L.J. 393 (2000) (proposing that the bankruptcy discharge is essential to fostering entrepreneurship); Karen Gross, Failure and Forgiveness: Rebalancing the Bankruptcy System 91.104 (1997) (emphasizing forgiveness as the explanation for the bankruptcy discharge); Charles G. Hallinan, The 'Fresh Start' Policy in Consumer Bankruptcy: A Historical Inventory and an Interpretative Theory, $21 \mathrm{U}$. Rich. L. Rev. 49 (1986) (reviewing the literature up to that time); Margaret Howard, A Theory of Discharge in Consumer Bankruptcy, 48 Oнıо Sт. L.J. 1047 (1987) (suggesting that discharge is necessary to restore the debtor to a participation in an open credit economy); Richard M. Hynes, Why (Consumer) Bankruptcy?, 56 ALA. L. REV. 121 (2004) (urging that through amendment of non-bankruptcy collections laws, society could largely replicate the fresh start offered by the bankruptcy discharge without the need for any formal proceeding at all); Thomas H. Jackson, The Fresh-Start Policy in Bankruptcy Law, 98 HarV. L. REV. 1393 (1985) (viewing financial failure in the market as stemming from inherent volitional disabilities or cognitive biases of individuals, which only a "paternalistic," "socially mandated" rule such as a nonwaivable discharge can solve by giving creditors the incentive to police debtors' credit decisions); Michael D. Sousa, The Principle of Consumer Utility: A Contemporary Theory of Bankruptcy Discharge, 58 U. KAN. L. REv. 553 (2010) (proposing a "consumer utility" theory of consumer bankruptcy); Charles Jordan Tabb, The Scope of the Fresh Start in Bankruptcy: Collateral Conversions and the Dischargeability Debate, 59 Geo. WAsh. L. Rev. 56 (1990) (reviewing the literature). See also Charles W. Mooney, A Normative Theory of Bankruptcy Law: Bankruptcy as (is) Civil Procedure, 61 WASH LeE L. ReV. 931, 1050 (2004) (observing that, "Clearly no consensus exists as to the justification for the bankruptcy discharge and the debtor's corresponding fresh start. Theories abound-some are competing, some are complementary. Interestingly, there does seem to be agreement approaching consensus among many (but not all) academics that the discharge generally is justified, that current law has it about right ...."). 
assailable reality is that we do have a consumer bankruptcy system, and one that simultaneously serves multiple purposive objectives. ${ }^{2}$ In recent years, the circumstances under which relief may be sought, and by whom, have witnessed a significant contraction. ${ }^{3}$ Regardless, however, of whatever additional goals the system seeks to attain, and who is considered eligible for relief, the most notable consequence of the consumer bankruptcy system re. mains the availability of the fresh start for a financially beleaguered individ. ual, ${ }^{4}$ a construct without analog under state law. ${ }^{5}$

\footnotetext{
${ }^{2}$ The bankruptcy law is intended to serve simultaneously as a more efficient and effective debt collection device for creditors as well as a mechanism to provide relief to the financially distressed debtor. See Louis Edward Levinthal, The Early History of Bankruptcy Law, 66 U. PA. L. Rev. 223, 225 (1918) ("All bankruptcy law ... no matter when or where devised and enacted, has at least two general objects in view .... [It] seeks to protect the creditors, first, from one another and, secondly, from their debtor. A third object, the protection of the honest debtor from his creditors, by means of the discharge, is sought to be attained in some of the systems of bankruptcy, but this is by no means a fundamental feature of the law."); Robert E. Scott \& Thomas H. Jackson, On the Nature of Bankruptcy: An Essay on Bankruptcy Sharing and the Creditors' Bargain, 75 VA. L. Rev. 155 (1989). Indeed, voluntary bankruptcy and the concept of "discharge" are relatively recent features of the bankruptcy law, which, historically, was exclusively a creditors' remedy. See John C. McCoid, II, Discharge: The Most Important Development in Bankruptcy History, 70 AM. BANKR. L.J. 163 (1996).

${ }^{3}$ Since 2005 , under 11 U.S.C. $\$ 707$ (b) debtors are "means tested" to determine their ability pay back all or a substantial portion of their debts. A debtor who is determined to be "can pay" is excluded from relief under Chapter 7 of Title 11, and must instead seek recourse, if at all, under Chapter 13 (requiring proposal and confirmation of a debt repayment plan). Judge Edith H. Jones \& Todd J. Zywicki, It's Time for Means-Testing, 1999 BYU L. Rev. 177 (1999). The means test was controversial to say the least in terms of both its desirability and its effectiveness. See David G. Carlson, Means Testing: The Failed Bankruptcy Revolution of 2005, 15 AM. BANKR. INST. L. ReV. 223 (2007) (arguing that the means test has driven up the cost to consumer debtors with no corresponding benefits either in terms of decreasing debtor abuses or increasing creditor pay outs). See generally, Jean Braucher, Rash and Ride-Through Redux: The Terms for Holding on to Cars, Homes and Other Collateral Under the 2005 Act, 13 AM. BANKR. INST. L. Rev 457, 458-59 n.3 (2005) (suggesting that some debtors who could easily pass the means test but, in the past would have chosen Chapter 13, will now elect relief under Chapter 7 because of the higher repayment requirements also imposed in 2005 to retain cars and other personal property collateral).
}

${ }^{4}$ The phrase "fresh start" derives from the early twentieth century Supreme Court decision Local Loan Co. v. Hunt, 292 U.S. 234, 244 (1934). Bankruptcy gives "the honest but unfortunate debtor who surrenders for distribution the property which he owns at the time of bankruptcy, a new opportunity in life and a clear field for future effort, unhampered by the pressure and discouragement of pre-existing debt." Id. (emphasis added). More recently, the Supreme Court referred to the fresh start as "the principal purpose of the Bankruptcy Code." Marrama v. Citizens Bank of Massachusetts, 549 U.S. 365, 367 (2007). In another context, I described the fresh start as "neither a formal legal status nor a cognizable right in the usual sense of the terms. Instead, it represents an aspiration of the bankruptcy system. It is the condition that is intended to result from application of specific bankruptcy rules in particular cases." Lawrence Ponoroff, Vicarious Thrills: The Case for Application of Agency Rules in Bankruptcy Dischargeability Litigation, 70 TuL. L. Rev. 2515, 2519 (1996).

${ }^{5} \mathrm{~A}$ few of the American colonies, however, did offer a limited form of discharge. See Jonathan C. Lipson, Debt and Democracy: Towards a Constitutional Theory of Bankruptcy, 83 Notre Dame L. Rev. 605, 626 (2008) (citing Peter J. Coleman, Debtors and Creditors in America 14 (1974)). The federal Constitution specifically, bars the states from granting a general discharge by virtue of the Contract Clause, which forbids the states from retroactively passing laws that impair the obligation of con- 
By dint of the U.S. Constitution, ${ }^{6}$ bankruptcy law in this country is uniquely federal law in the sense that when Congress choses to legislate in the field, 7 it does so to the exclusion of state law. ${ }^{8}$ And, yet, ever since the first long-standing federal bankruptcy law was enacted in $1898,{ }^{9}$ state law has continued to play a vital interstitial role in defining the commercial rights, interests and entitlements of participants in the bankruptcy case. ${ }^{10}$ Thus, it is not in the leastwise inconsistent to say that while state commercial law must yield to federal bankruptcy law; bankruptcy law cannot operate other than against the backdrop of state commercial law. This creates, at certain times and in certain places, an uneasy co-existence and division of authority between the two systems. Perhaps nowhere is this lack of synchronicity as sharply in focus as in connection with the determination of the exemptions to

tracts. U.S. CONST. art. $1, \$ 10$, cl. 1. The concepts of voluntary bankruptcy for all debtors and discharge were also largely unknown in national bankruptcy legislation until the Bankruptcy Act of 1841 . See generally Charles Jordan Tabb, The History of the Bankruptcy Laws in the United States, 3 AM. BANKr. INST, L. REV. 5, 16-18 (1995).

${ }^{6}$ U.S. Const. art. I, $\$ 8$, cl. 4. See generally Charles Warren, Bankruptcy in United States History 4 (1935) (suggesting that the location of the Bankruptcy Clause immediately after the. Commerce Clause was not accidental).

${ }^{7}$ See Brown v. Smart, 145 U.S. 454, 457 (1892) ("So long as there is no national bankrupt act, each state has full authority to pass insolvent laws binding persons and property within its jurisdiction, provided it does not impair the obligation of existing contracts; but a state cannot by such a law discharge one of its own citizens from his contracts with citizens of other states ...."). This principle was established early by Chief Justice Marshall in Sturges v. Crowninshield, 17 U.S. (4 Wheat.) 122, 193-96 (1819), although, just eight years later, and over the Chief Justice's dissent, the Court concluded that the prohibj. tion only applied retrospectively. Ogden v. Saunders, 25 U.S. (12 Wheat.) 213 (1827).

${ }^{8}$ The Supremacy Clause of the United States Constitution gives Congress authority to preempt any state law that conflicts with the exercise of federal power. U.S. Const. art. VI, cl. 2. See also Sturges, 17 U.S. at 191 ("Whenever the terms in which a power is granted to congress, or the nature of the power, require that it should be exercised exclusively by congress, the subject is as completely taken from the state legislatures, as if they had been expressly forbidden to act ....")

${ }^{9}$ Bankruptcy Act of 1898, Ch. 541, 30 Stat. 544, 548, repealed by Bankruptcy Reform Act of 1978, Pub. L. No. 95-598, 92 Stat. 2549.

${ }^{10}$ Although the Bankruptcy Clause clearly empowers Congress to define the substantive rights that interested parties in a bankruptcy case would enjoy against the debtor and inter se, Congress has not elected to enact a federal commercial law, thus leaving the determination of property rights in assets of a bankruptcy estate to state law, except where some federal interest compels a different right. See Butner v. United States, 440 U.S. 48, 55 (1979) (holding that unless some federal interest requires a different result, state law should apply), superseded by statute as recognized in In re White Plains Dev. Corp., 137 B.R. 139 (Bankr. S.D.N.Y. 1992). It is, however, easy to read Butner too broadly insofar as deference to state law is concerned. See generally Lawrence Ponoroff, Reclaim This! Getting Credit Seller Claims in Bankruptcy Right, 48 U. Rich. L. REV. 733, 789 (2014) (“'W]e all bow to Butner, but, in truth, the principle articulated in Butner represents no more than a bias. By definition, then, it applies more often than not, but it is not an absolute that substitutes for reasoned analysis in each instance where federal and state law intersect."). In In re NM Holdings Co., 407 B.R. 232 (Bankr. E.D. Mich. 2009), for instance, the court, relying on Sixth Circuit precedent regarding the scope of $\S 105(\mathrm{a})$, rejected the creditors' argument that the Butner principle deprived the court of authority to order substantive consolidation. The court noted there is an overriding federal interest in the equitable and efficient distribution of a debtor's property among its creditors, and, in the case of conflict with state property law, bankruptcy policy must prevail. Id. at 277. 
which a debtor who has filed under Chapter 7 of the federal Bankruptcy Code ${ }^{11}$ is entitled to claim in her bankruptcy case; an area where Congress has explicitly deferred, but far from wholly yielded, to state law.

The general awkwardness of the marriage between state and federal law in bankruptcy is exacerbated by the fact that, at their core, the two systems imagine a very different sort of problem to which each is responding. The former is concerned with balancing the respective rights of a creditor and a debtor in connection with a specific debt-collection matter. That is to say, it envisions a two-party dispute and endeavors to set the parameters governing the formal choreography of that particular contest. Federal bankruptcy law, by contrast, takes a much broader survey of the terrain. It addresses not only the correlative rights and obligations of the debtor vis-à-vis each of her creditors, but also the rights of all of those creditors inter se. ${ }^{12}$ Bankruptcy, in other words, is distinct from state law in that it is concerned with a collectiv. ized debt collection process in which considerations of equality of distribution among, and maximization of value for, creditors (concerns to which state law is largely oblivious) all factor into a comprehensive and intricate scheme for wrapping up the debtor's prepetition financial life and, ideally, providing the debtor with a path to financial viability in the future. ${ }^{13}$

The history of exemption policy in American bankruptcy law is a long and largely undistinguished one, stained far more often by partisan political posturing and compromise than exemplified by high-minded principle. For instance, in 1970, Congress established the Commission on the Bankruptcy Law of the United States and charged it with a mandate to "study, evaluate and recommend changes to [the existing bankruptcy law]."14 Roughly three years later, the Commission issued its final Report consisting of findings and recommendations in Part I, and a proposed reform bill in Part II. Among its

${ }^{11}$ The current law of bankruptcy is found in Title 11 of the United States Code. 11 U.S.C. $\$ \S 101$. 1530 (2012), as amended through Pub. L. No. 112-106, 126 Stat. 306 (amended 2012). It was enacted on November 6, 1978 as the Bankruptcy Reform Act of 1978, Pub. L. No. 95-598, 92 Stat. 2549, and governs all cases filed on or after October 1, 1979. In this Article, except where otherwise indicated, all references herein to the "Code" or the "Bankruptcy Code" are to Title 11 of the United States Code as amended through January 1, 2013.

${ }^{12}$ See generally Vern Countryman, For a New Exemption Policy in Bankruptcy, 14 Rutgers L. ReV. 678,681 (1960) ("State exemption laws are not designed primarily for use in a system of orderly liquidation where all of the debtor's estate is to be converted to cash, but in a system of piecemeal liquidation where each creditor levies upon and sells such property as he can locate."); THOMAS H. JACKSON, THE LOGIC AND LIMITS OF BANKRUPTCY LAW 2.4 (1986) (emphasizing the role of bankruptcy as a collective debt collection device to address the "common pool" problem that exists when the debtor's assets are insufficient to satisfy the demands of all of the debtor's creditors).

${ }^{13}$ See Lawrence Ponoroff \& F. Stephen Knippenberg, The Immovable Object Versus the Irresistible Force: Rethinking the Relationship Between Secured Credit and Bankruptcy Policy, $95 \mathrm{MICH}$. L. REv. 2234, 2290-91 (1997) (pointing out that it is the point of bankruptcy to draw a sharp line of demarcation; to close the books on the debtor's prepetition financial life).

${ }^{14}$ Act of July 24, 1970, Pub. L. No. 91-354, 86 Stat. 468. 
recommendations in Part I, the Commission urged that a uniform set of federal exemptions apply in all bankruptcy cases, superseding state and other nonbankruptcy federal laws granting or restricting exemptions. ${ }^{15}$ The Commission explained that even though the ability to exempt income and assets from administration was, along with the discharge of debts, an essential feature of the financial fresh start for individual debtors, the then-current Bankruptcy Act's deference to applicable state and other federal exemption schemes meant that the exemptions available in any given case were the result not of "reasoned policy," but rather of the serendipity of "history and location." 16 This, the Commission concluded, was intolerable under what is supposed to be a uniform, national system, and represented a situation that the Commission described as destructive "to the goal of rehabilitation of individual debtors." 17

The Commission's recommendation regarding exemptions was greeted with a firestorm of opposition, largely political in origin. ${ }^{18}$ The compromise ultimately reached to secure enactment of the Bankruptcy Reform Act of 1978 is the approach of election and opt-out that persists to the present day. ${ }^{19}$ That is, the debtor is given the option to choose either to have her exemptions determined under a set of federal bankruptcy exemptions set forth in $\$ 522(\mathrm{~d})$ of the Code or under applicable state (and other federal nonbankruptcy) law. ${ }^{20}$ The states, in turn, have their own option; the Code

\footnotetext{
${ }^{15}$ Comm'n on the Bankr. Laws of the U.S., Report of the Commission on the Bankruptcy Laws of the United States, H.R. Doc. No. 93.137, at 170-173 (1973).

${ }^{16} I d$. at 169.

${ }^{17}$ Id. Of particular relevance to the position advanced in this article, the Report also pointed out that the use of nonbankruptcy law to determine the exemptions had, "contrary to the goals of federal bankruptcy legislation, allowed some creditors to be preferred over others and caused substantial nonuniformity." Id. at 171. It is interesting to note that the Executive Director of the Commission was Professor Frank Kennedy who, a bit more than a decade earlier, had penned a law review article supporting the states' interest in defining exemptions over the effectiveness and uniformity that might be derived from "superimposing designation or limitation on exemptions ...." Frank R. Kennedy, Limitations of Exemptions in Bankruptcy, 45 IowA L. REV. 445, 451 (1960). For a sharply conflicting view written about the same time, see Countryman, supra note 12, at 683 (describing state exemptions at the time as obsolete "both in the type of property exempted and in the amount of the value limits").

${ }^{18}$ The objections were predicated nominally on historic states' rights arguments, as well as a fear that mandatory federal exemptions would trigger an enormous increase in bankruptcy filings, either by debtors in states with less generous exemptions from judgment execution, or by creditors in states whose exemp. tions were more generous than those allowed under the federal scheme. See Hon. William H. Brown, Political and Ethical Considerations of Exemptions Limitations: The "Opt-Out" as Child of the First and Parent of the Second, 71 AM. BANkR. L.J. 149 (1997); Lawrence Ponoroff, Exemption Limitations: A Tale of Two Solutions, 71 AM. BANKR. L.J. 221, 223 (1997). See also infra text accompanying notes 244-247.

${ }^{19} \mathrm{For}$ discussion of the background and the legislative history surrounding the Code's approach to exemptions, see James B. Haines, Jr., Section 522's Opt-Out Clause: Debtors' Bankruptcy Exemptions in a Sorry State, 1983 Ariz. St. L.J. 1, 6-10 (1983). See also Teresa A. Sullivan et Al., As We Forgive our Debtors: Bankruptcy and Consumer Credit in America 28 (1989) (suggesting that, "Congress once again sidestepped a sticky political issue by leaving the decision to state legislatures.").

${ }^{20}$ As suggested in the text, the alternative to $\S 522$ (d) for a debtor is the exemptions provided for
} 
confers authority on the states to adopt legislation barring their residents who become bankruptcy debtors from electing the federal bankruptcy exemptions set forth in $\$ 522$ (d) of the Bankruptcy Code. This is the so-called "opt-out" provision of $\S 522(\mathrm{~b})(2),{ }^{21}$ of which thirty-four states have availed themselves. ${ }^{22}$ Debtors in these jurisdictions must have their exemptions defined by state law, as was the practice under the former Bankruptcy Act. ${ }^{23}$

In 1994, Congress created another blue-ribbon commission, the National Bankruptcy Review Commission (the "NBRC"), to study and recommend changes to the Code. ${ }^{24}$ In its 1997 Report, ${ }^{25}$ the NBRC recommended sev. eral modifications in the provisions governing exemptions allowable to debtors in bankruptcy. Chief among them, however, was, once more, the recommendation of greater uniformity and coherence by means of enhanced federal preemption over the determination of exemptions in bankruptcy. ${ }^{26}$ The NBRC's recommendations in the exemption arena were intended to assure minimum adequate exemptions for debtors in states with very restrictive exemption laws, and simultaneously to control abusive prebankruptcy planning involving the use of overly generous or unlimited exemptions in other states.

The NBRC's recommendations regarding exemptions, like virtually all of its other recommendations, essentially were ignored, as the lobby for consumer creditor organizations anticipated and attempted to ambush the major-

under federal non-bankruptcy law as well as state law, plus (1) exemptions applicable to property held as tenants by the entireties or joint tenants, and, since, 2005 (2) most types of tax-exempt retirement assets. See Code $\$ \S 523(b)(3)(B)$ and $(C)$. In the interests of convenience and simplicity of presentation, however, and because in the vast majority of instances it is also what matters principally, the article frequently uses the phrase "state law" as a shorthand reference to all exemptions available to a debtor under Code $\S 522(\mathrm{~b})(3)$, and should be so regarded when the context requires.

${ }^{21}$ The pertinent language of the statute provides that exempt property shall be as listed under $\S 522$ (d), "unless the State law that is applicable to the debtor under paragraph 3(A) [of this section] specifically does not so authorize."

${ }^{22}$ In addition to the seventeen non-opt states, the District of Columbia and each of the U.S. territories have chosen not to opt-out, thus permitting their citizens who file for bankruptcy to elect between state and federal exemptions. See William Houston Brown et al., Bankruptcy Exemption Manual App. C (West 2010).

${ }^{23}$ See infra note 56 and accompanying text.

${ }^{24}$ See Bankruptcy Reform Act of 1994, Pub. L. No. 103-394, tit. VI, §603, 108̉ Stat. $4106,4147$.

${ }^{25}$ Nat'l Bankr. Review Comm'n, Bankruptcy: The Next Twenty Years (1997) (NBRC Report).

${ }^{26}$ Specifically, the Commission recommended elimination of the opt-out and that exemptions of income and personal property be determined under the federal bankruptcy law, with the exemption stated in a single, lump-sum cash amount (except for special categories of personalty, such as professionally prescribed medical devices and health aids) with the debtor to determine how the cash allowance is to be allocated. Id. at 105-116. As for the homestead exemption in bankruptcy, the Report called for it to continue to be governed by applicable state law, but subject to a federally-imposed floor and ceiling. Id. at 121-144. In the interests of full disclosure, the NBRC's recommendations regarding exemptions largely followed the analysis that had been prepared by Judge William H. Brown and me. See G.1.b to the NBRC Report, available at http://govinfo.library.unt.edu/nbrc/report/glb.pdf. 
ity report by pressing furiously for the introduction of bipartisan legislation that advanced the views of the four dissenting members of the Commission. ${ }^{27}$ They were ultimately successful. That legislative proposal, and it successors, dominated the conversation over the next several years, and eventually resulted in the enactment in 2005 of the Bankruptcy Abuse Prevention and Consumer Protection Act (BAPCPA). ${ }^{28}$ As opposed to the NBRC's balanced and straightforward approach to exemption policy in bankruptcy, BAPCPA characteristically ignored the issue of minimally sufficient exemptions for debtors residing in opt-out states with miserly exemptions, ${ }^{29}$ and, in its uniquely inelegant style, ${ }^{30}$ established an elaborate, confusing, and dreadfully convoluted scheme for attempting to control the practice of abusing high dollar or unlimited state exemptions through forum-shopping and the excessive conversion of nonexempt assets to exempt form on the eve of bankruptcy. ${ }^{31}$

${ }^{27}$ NBRC Report, supra note 25 , at 1029 , et seq. (Individual Commissioner views). See generally A. Mechele Dickerson, Regulating Bankruptcy: Public Choice, Ideology, $\mathcal{E}$ Beyond, 84 WAsH. U. L. Rev. 1861, 1865 (2006) (noting that before the NBRC's Report was even filed, the credit lobby found support. ers in the 105th Congress to sponsor legislation adopting the views of the dissenting Commissioners).

${ }^{28}$ Pub. L. No. 109-8, 119 Stat. 23 (2005) (codified as amended in scattered sections of 11 U.S.C.). BAPCPA became fully effective for cases filed on or after Oct. 17, 2005. See Susan Jensen, A Legislative History of the Bankruptcy Abuse Prevention and Consumer Protection Act of 2005, 79 AM. BANkR. L.J. $485,512-15$ (2005) (tracing the progression of the bills, beginning with the 1997 bill that preempted the NBRC's Report, that eventually resulted in the passage of BAPCPA).

${ }^{29} 1$ say "characteristically" because BAPCPA was widely (and not inaccurately) criticized as having been bought and paid for by the consumer credit industry. See, e.g., 151 Cong. Rec. S2216 (daily ed. Mar. 8, 2005) (statement of Sen. Durbin); 151 Cong. ReC. H2084 (daily ed. Apr. 14, 2005) (statement of Rep. McDermott). While this may be a bit of an overstatement, and despite the "consumer protection" language in its title, no one would argue that BAPCPA was other than a creditors" bill. See Milavetz, Gallop \& Milavetz, P.A. v. United States, 559 U.S. 229, 231-32 (2010) (noting that Congress enacted BAPCPA in order "to correct perceived abuses of the bankruptcy system.").

${ }^{30}$ See Ponoroff, supra note 10, at 733-34 (describing BAPCPA as "clumsily drafted, unnecessarily prolix, internally inconsistent, and annealed in a cauldron of special interest pressures."). See also Braucher, supra note 3, at 457 n.3 (noting that some have taken to calling BAPCPA "by the fanciful acronym BARF (BAnkrutcy ReForm Act) $)^{\top}$ ).

${ }^{31}$ Instead of responding to the problem by the simple expedient of capping the homestead exemption as recommended by the NBRC, BAPCPA extended from 91 to 730 days the number of days prior to filing that a debtor must reside in a state in order to claim that state's exemptions. See Code $\$ 522(b)(3)(A)$. In addition, $\$ 522(\mathrm{p})(1)$ was added to the Code by BAPCPA, providing that with respect to real property acquired by the debtor within the 1215-day period prior to bankruptcy, and claimed by the debtor under state law as a homestead, the exemption may not exceed $\$ 125,000$ (subsequently indexed to $\$ 155,675$ as of April 1, 2013). Finally, to deal with homestead property acquired outside the 1215-day period: (1) $\$ 522(0)(4)$ of the Code provides a ten-year disallowance for exemptions obtained by means of the fraudulent conversion of nonexempt assets to exempt form; and (2) $\$ 522(q)(1)$ also limits the homestead exemp. tion to $\$ 155,675$, and imposes other possible sanctions for debtors guilty of felony demonstrating that "the filing of the case was an abuse of the provisions of this title," or one of the enumerated acts of wrongdoing, including securities fraud, in $\$ 522(q)(1)(B)$. This is the so-called "Enron" provision, supposedly aimed at ensuring that executives guilty of the kind of contretemps as were involved in that case are not able in the future to shield enormous amounts of assets through state exemption laws. See Charles Jordan TABB, LAW OF BANKRUPTCY $\$ 9.5,897$ (3d. ed. 2013). 
The next chapter in the pull and tug between state and federal authority over the issue of exemptions developed in a manner not contemplated by the Code and likely never anticipated even by the early supporters of state he. gemony over the determination of exempt property in bankruptcy. Specifically, just as the legitimacy (albeit perhaps not the wisdom) of the Code's opt-out scheme became settled policy, ${ }^{32}$ the courts began to grapple with the constitutionality of special state-promulgated bankruptcy-specific exemptions, a phenomenon dating back to $1980,{ }^{33}$ but one that has proliferated in the last decade or so. ${ }^{34}$ Under the typical pattern, a debtor who elects, or is required by state opt-out legislation, to have her exemptions defined by state law is allowed to claim often more favorable exemptions in her bankruptcy case than the exemptions from conventional judgment execution to which she otherwise would have been entitled in that jurisdiction absent a bankruptcy filing.

These bankruptcy-specific exemption statutes have been challenged, successfully on some occasions, ${ }^{35}$ on constitutional grounds, but two circuit courts of appeal, ${ }^{36}$ and two bankruptcy appellate panels ${ }^{37}$ have now held that

\footnotetext{
${ }^{32}$ See authorities cited infra note 61.

${ }^{33}$ See infra notes 65.66 and accompanying text.

${ }^{34}$ See, e.g., Heather M. Forrest, Are Bankruptcy-Specific State Exemptions Constitutional?, XXXI ABI
} JourNal 10, 14, 86 (November 2012) (discussing the legislative history of the Michigan statute that became effective in 2005).

${ }^{35}$ See In re Reinhart, 460 B.R. 466 (Bankr. E.D. Mich. 2011); In re Pontius, 421 B.R. 814 (Bankr. W.D. Mich. 2009); In re Wallace, 347 B.R. 626 (Bankr. W.D. Mich. 2006). Compare In re Cross, 255 B.R. 25 (Bankr. D. Ind. 2000), In re Reynolds, 24 B.R. 344 (Bankr. S.D. Ohio 1982), and In re Regevig, 389 B.R. 736 (Bankr. D. Az. 2008) (all striking a state-enacted bankruptcy statute on the basis of the Supremacy Clause), with In re Mata, 115 B.R. 288 (Bankr. D. Colo. 1990) and In re Lennen, 71 B.R. 80 (Bankr. N.D. Cal. 1987) (both declaring bankruptcy-specific state exemption laws invalid under the Supreme Court's definition of uniformity, for purposes of the Bankruptcy Clause, established in Hanover Nat'l Bank v. Moyses, 186 U.S. 181 (1902)). These decisions are now all either superseded or, even if not abrogated by subsequent authority, cast into some doubt by virtue of later nonbinding negative authority. See cases cited infra notes $36-37$. Commentators have also questioned the lawfulness of bankruptcy-only state legislation. See, e.g., Joseph Lamport, The Preemption of Bankruptcy Only Exemptions, 6 CARDozo L. Rev. $583,584-85$ (1985) (arguing that the plenary bankruptcy power granted to Congress completely preempts states from creating bankruptcy-specific exemptions); Edward Stechschulte, Comment, The (Un)constitutionality of State-Enacted Bankruptcy-Specific Exemptions: Using Ohio Revised Code Section 2329.66(A)(18) as a Mechanism for Analysis, 40 U. TOL. L. REV. 761 (2009).

${ }^{36}$ Richardson v. Schafer (In re Schafer), 689 F.3d 601 (6th Cir. 2012), cert. denied, 133 S. Ct. 1244 (2013); Sheehan v. Peveich, 574 F.3d 248 (4th Cir. 2009). In addition, in Kulp v. Zeman (In re Kulp), 949 F.2d 1106 (10th Cir. 1991), the court rejected the trustee's challenge to a Colorado statute that permitted a debtor, "only for purposes of claiming an exemption in bankruptcy," an exemption for pension or retirement benefits, including an IRA. In a footnote, that court also rejected an alternative argument raised by the trustee challenging the state stature on the basis of the uniformity requirement in the Bankruptcy Clause. Id. at 1109 n.3. The court observed that both Mata and Lennen, on which the trustee relied, misapprehended the holding in Moyses. Id. See also infra notes 153-154 and accompanying text.

${ }^{37}$ Williamson v. Westby (In re Westby), 486 B.R. 509 (B.A.P. 10th Cir. 2013); Sticka v. Applebaum (In re Applebaum), 422 B.R. 684 (B.A.P. 9th Cir. 2009). 
these bankruptcy-only laws neither impinge on Congress' constitutional authority to enact "uniform laws on the subject of Bankruptcy," nor are preempted by virtue of the Supremacy Clause of the Constitution. ${ }^{38}$ The decision in the most recent of these courts of appeal cases, In re Schafer, ${ }^{39}$ from the U.S. Sixth Circuit, is perhaps the most compelling in that the careful opinion is authored by R. Guy Cole, Jr., who is not only a respected circuit judge, but one who previously enjoyed a distinguished career as a bankruptcy practitioner and judge.

Nonetheless, in this article it is alternatively argued that these state law bankruptcy-specific exemptions are constitutionally suspect, and, in any event, add further grist to the mill in support of the now forty-plus year effort to supplant state law with a system of mandatory uniform federal ex. emptions in bankruptcy. Part I begins with a brief overview of the history of exemption legislation and policy under federal bankruptcy law. Part II then examines the case law addressing the lawfulness of state law exemptions ap. plicable only in bankruptcy, with particular emphasis on Judge Cole's opinion in Schafer. Part III analyzes more closely the constitutional considerations implicated by these provisions, concluding that the issues are serious and sub. stantial, and likely to vex bankruptcy practice for some time to come. Lastly, Part IV updates and renews the case in favor of "federalizing" policy in this area. It urges that the constitutional showdown over bankruptcy-specific exemptions can and should be avoided by finally taking this step; that the political environment for doing so is favorable; and that the result would be a system that not only assures greater uniformity, but also one that advances the federal bankruptcy policies of equity, equality, and rehabilitation in a far more powerful and effectual fashion than the current regime.

\section{BANKRUPTCY EXEMPTIONS}

\section{A. BACKgRound}

The ability to protect exempt assets, however defined, together with the discharge of the debtor's in personam liability ${ }^{40}$ represent the principal components of the bankruptcy fresh start, ${ }^{41}$ although several subsidiary aspects of

\footnotetext{
${ }^{38}$ The Supremacy Clause appears in U.S. CoNsT. art VI, cl. 2, and, in pertinent part, provides that: "[t]his Constitution, and the Laws of the United States which shall be made in Pursuance thereof . . shall be the supreme Law of the Land." As a consequence, any act of a state legislature that interferes with, or is contrary to the laws enacted by Congress under its constitutional authority is invalid. Gibbons v. Ogden, 22 U.S. 1, 3 (1824).

${ }^{39}$ See supra note 36.

${ }^{40}$ See Code $\$ 727(\mathrm{a})$.

${ }^{41}$ See Ponoroff, supra note 4, at 2519-20 (identifying the fresh start as an "aspiration of the bankruptcy system" rather than a formal legal status or cognizable right, but referring to the discharge as the "defining aspect of the fresh start").
} 
the fresh start doctrine can be found and are implemented by other provisions of the Code. ${ }^{42}$ Every state, of course, also recognizes today the need or desir. ability for certain property and/or income to be immune from execution by judgment creditors, ${ }^{43}$ although these exemption schemas vary widely in scope, content, and amount. ${ }^{44}$ As is not uncommon in a federal system, ex. emptions in bankruptcy operate differently than they do under state law. Most notably, in a bankruptcy case, exempt assets are immune not from execution, as under state law, but rather from liquidation by the trustee and distribution to creditors. ${ }^{45}$ Thus, the exempt assets, or in some instances a portion of the value of such assets, ${ }^{46}$ remain with the debtor to prime her fresh start. Further, these assets remain permanently free from execution to

\footnotetext{
${ }^{42}$ These include the ability to avoid certain exemption-impairing liens under Code $\$ 522(f)$; the protection against discriminatory treatment in Code $\$ 525$; and the right of redemption under Code $\$ 722$. Cf Rafael I. Pardo \& Michelle R. Lacey, Undue Hardship in the Bankruptcy Courts: An Empirical Assessment of the Discharge of Educational Debt, 74 U. CIN. L. Rev. 405, 415-16 n.39 (2005) (expressing the view that the discharge in bankruptcy by itself constitutes the fresh start, and that other provisions of the Code - that relate to the fresh start do so only in the sense of its implementation and protection, rather than its substance).

${ }^{43}$ Actually, exemption laws date back to Roman times. See Levinthal, supra note 2, at 238. Although bankruptcy law began in England purely as a creditors' collection remedy, the Act of 4 Anne, ch. 17 (1705), first authorized bankrupts to keep their clothing and up to $5 \%$ of their remaining property as , exempt from their creditors. See Emily Kadens, The Last Bankrupt Hanged: Balancing Incentives in the Development of Bankruptcy Law, 59 DuKE L.J. 1229 (2010).

${ }^{44}$ Property exemptions can be determined by type, category, dollar amount, or, quite commonly, a type but subject to a maximum dollar amount limit, e.g., "one automobile up to a value of $\$ 5,000$." Although now out-of-date, the wide variety and disparities in exemption schemas are illustrated by the state by state comparison set forth in Brown, supra note 18, at 218.19 (App. II). The current exemption laws of all 50 states, as well as Puerto Rico and the U.S. Virgin Islands, are collected in Vols. 12 \&'13, Collier ON BANKRUPTCY (16th ed. 2013). While many states have updated and modernized their exemptions laws since the adoption of the Code, see infra note 248 , significant differences persist. For instance, the homestead exemption in Alabama, an opt-out jurisdiction, is currently limited $\$ 5,000(\$ 10,000$ for a married couple entitled to claim separately). ALA. CODE $§$ 6-10-2. As noted, by contrast, in Texas, the homesteadd exemption remains limited only by acreage (up to 200 acres in non-urban areas). Tex. Const. arts. 50 \& 51. Thus, the fresh start for a Mobile-based debtor can be quite different from her counterpart in Dallas.

${ }^{45}$ See generally' Sticka v. Applebaum (In re Applebaum), 422 B.R. 684, 694 (B.A.P. 9th Cir. 2009) (Markell, J., dissenting) (noting the significance of this distinction in terms of avoiding interference with the federal bankruptcy distribution scheme); Brown, supra note 18, at 181 (observing that in contrast to the single creditor orientation of non-bankruptcy exemptions, bankruptcy is designed to offer relief as to creditor collection efforts in general); Countryman, supra note 12; William T. Vukowich, Debtors' Exemption Rights Under the Bankruptcy Reform Act, 58 N.C. L. Rev. 769, 802 (1980) (describing the different function of exemptions under, respectively, state and federal bankruptcy law). This, in part, explains why the Bankruptcy Code's deference to state law in the area of exemptions is far from complete. For instance, while the granting a security interest in property is implicitly a subordination of the exemption to the extent of the secured debt, in bankruptcy that rule is subject to the debtor's ability to avoid certain exemption impairing liens under $\$ 522(\mathrm{f})$. See also infra text accompanying notes 222.224 for additional examples.

${ }^{46}$ While we commonly talk of property as being exempt or non-exempt, in many, if not most cases, the exemption is subject to a dollar-denominated cap, such that "exempt property" is often sold so that the value in excess of the dollar limitation can be realized upon either by the executing creditor or the bank. ruptcy trustee.
} 
satisfy virtually all prepetition claims, including those deemed to be nondischargeable, even after the bankruptcy case is concluded. 47

The earliest bankruptcy legislation in the United States, the Bankruptcy Acts of $1801^{48}$ and 1841,49 each established a uniform set of federal exemptions that preempted the exemption laws of the debtor's state of residence. ${ }^{50}$ The last of the short-term American bankruptcy laws, the Bankruptcy Act of $1867,,^{51}$ provided for a limited set of federal exemptions, but also, for the first time, allowed the debtor (then known as the "bankrupt"52) to claim her applicable state law exemptions as well.53 The issue of whether state or federal exemptions would control in nineteenth century bankruptcy legislation was contentious; an artifact of the larger battle between agrarian interests in the Old South and the West, which generally sought to curb any expansion of federal power over debt collection law, and the largely urban, commercial interests in the Northeast, which typically lobbied for more effective national legislation. ${ }^{54}$

As observed earlier, the Bankruptcy Act of 1898 abandoned entirely any federal definition of exempt property and instead simply deferred to applicable state law when it came to defining the exemptions to which the bankrupt

${ }^{47}$ See Code $\$ 522(\mathrm{c})$, which other than four enumerated categories of debts, sets forth the general rule that property determined to be exempt under $\S 522$ is not liable, during or after the case, for any debt that arose (or is deemed to have arose) prior to filing of the petition, regardless of what state law has to say in relation to limitations on exempt property.. Of course, because of the discharge, even if property is converted after the case to nonexempt form it remains-unlike under state law-beyond the reach of most prepetition creditors.

${ }^{48}$ Act of Apr. 4, 1800, ch. 19, 2 stat. 19, repealed by Act of Dec. 19, 1803, ch. 6,2 Stat. 248.

${ }^{49}$ Until the Bankruptcy Act of 1898 , nineteenth century bankruptcy legislation represented shortterm responses to financial turmoil (or panics) that were quickly repealed by Congress as soon as the crises passed. See generally David A. Skeel, JR., Debt's Dominion: A History of Bankruptcy Law in AMERICA 24-28 (2001).

${ }^{50}$ Act of Aug. 19, 1841, ch. 9, 5 Stat. 440, 443 (repealed). For discussion of the early American bankruptcy legislation, see Vern Countryman, A History of American Bankruptcy Law, 81 Com. L.J. 226 (1976); Rhett Frimet, The Birth of Bankruptcy in the United States, 96 Com. L.J. 166 (1991); Tabb, supra note 5 , at $12-18$.

${ }^{51}$ Act of Mar. 2, 1867, ch. 176, 14 Stat. 517, 523, repealed by Act of June 7, 1878, ch. 160, 20 Stat. 99.

${ }^{52}$ Indeed, the term "bankrupt ${ }^{n}$ to refer to the party subject to the proceeding persisted until it was replaced by the less pejorative term "debtor" by the Bankruptcy Reform Act of 1978. See Code $\S 101(13)$.

${ }^{53}$ Section 14 of the Act gave the bankruptcy assignee (now the trustee) title to all of the bankrupt's property, save for certain necessaries, not to exceed in value $\$ 500$, together with "such other property as now is, or hereafter shall be, exempted from . . . execution ... by the laws of the State in which the bankrupt has his domicile." See also Charles Warren, Bankruptcy in United States History 106. 07 (1935) (explaining that the preservation of state property exemptions in bankruptcy was necessary to appease conflicting factions in Congress, and that the constitutionality concerns, though raised, were squelched based, prophetically, on the same reasoning as the Supreme Court would adopt in Moyses).

${ }^{54}$ See, WARREN, supra note 6, at 8-9, 17-19. Cf. Skeel, supra 49, at $28-32$ (suggesting that the bank. ruptcy debates of the nineteenth century involved a multiplicity of often shifting views, rather than a clearly delineated battle between bankruptcy proponents and opponents). 
would be entitled. ${ }^{55}$ Section 6 provided that, "This Act shall not affect the allowance to bankrupts of the exemptions which are prescribed by the State laws in force at the time of the filing of the petition in the State wherein they have had their domicile for the six months immediately preceding the filing of the petition, or for a longer portion of such six months than in any other State." 56 While heralded as a victory for states' rights, ${ }^{57}$ the 1898 Act's approach introduced considerable disuniformity in terms of the type and extent of property that debtors from different states might retain following bankruptcy. This created a serious question at the time (and perhaps still today with respect to opt-out states) as to whether the Act's reliance on state exemptions, with no prescribed federal bankruptcy additions, was constitutional. In 1902, however, the Supreme Court of the United States, in Hanover National Bank v. Moyses, ${ }^{58}$ rejected a challenge to the Act based on the uniformity requirement in the Bankruptcy Clause of the Constitution. In that decision, the Court interpreted the Bankruptcy Clause as demanding only geographic and not intrinsic, personal uniformity. ${ }^{59}$ Thus, the Court concluded that "the general operation of the law is uniform although it may result in certain particulars differently in different states." 60 After enactment of the Bankruptcy Reform Act of 1978, several courts relied on the holding in Moyses to sustain the constitutionality of the election and opt-out provisions

\footnotetext{
${ }^{55}$ The National Bankruptcy Conference, a private organization composed of prominent bankruptcy lawyers, judges, and academics, considered proposing abandonment of the deferral to state exemptions in connection with the Chandler Act of 1938, which amended the Bankruptcy Act of 1898. Given that the Chandler Act was being crafted at the height of the Great Depression, this made eminent sense, but, according to Professor Koffler, the Conference ultimately backed off pushing for mandatory federal exemptions for fear that it would derail political support for the Act in its entirety. See Judith Schenck Koffler, The Bankruptcy Clause and Exemption Laws: A Reexamination of the Doctrine of Geographic Uniformity, 58 N.Y.U. L. REV. 22,26 n.10 (1983).

${ }^{56}$ Quite appropriately, the courts construed this language as essentially calling for deferral to state exemption laws in bankruptcy. E.g., Smalley v. Laugenour, 196 U.S. 93, 97 (1905).

${ }^{57}$ See SkEEL, supra note 49 , at 42 (commenting that incorporating state exemptions, a point of particular emphasis to southern legislators and a disappointment to most creditors, was likely the only way to get the Act passed).

${ }^{58} 186$ U.S. 181 (1902). The plaintiffs in Moyses also urged that $\S 6$ of the Act represented an unconstitutional delegation of power to the states, but the court gave short shrift to the argument, noting that the reference to "the loca! law in the matter of exemptions ... [was not an] attempt by Congress to unlawfully delegate its legislative power." Id. at 190.

${ }^{59}$ Id. at 188. See also Ry. Labor Execs. Ass'n v. Gibbons, 455 U.S. 457, 469 (1982) (“[U]niformity does not require the elimination of any differences among the States in their laws governing commercial transactions.").

${ }^{60}$ Moyses 186 U.S. at 190. See Koffler, supra note 55, at 95-96 (arguing that the Moyses Court's analysis was ahistorical and sacrificed the national interest in favor of the local, parochial concerns of the states). Professor Countryman earlier expressed a similar view. See Countryman, supra note 12, at 680-81 (suggesting that the Court equated requirement of uniformity to a requirement of fairness, and avoided any critical examination of the constitutionality of the system). See also infra text accompanying notes 142-145.
} 
in Code $\$ 522$ (b) under the standard of geographical uniformity. ${ }^{61}$ It is, how. ever, imperative to note that those decisions, like the Court's decision in Moyses, did not address the related, but in terms of its entailments quite different, question of whether states may enact exemptions that apply only in bankruptcy.

\section{B. Bankruptcy-Only Exemption Statutes}

While all sharing the same moniker, so-called "bankruptcy-specific statutes" come in a confusing array of diverse configurations. They range from comprehensive collections of exemptions (separate and apart from the state's general exemptions) applicable only to bankruptcy debtors, to discrete income or property exemptions that augment the jurisdiction's general exemptions in the case of a bankruptcy filing. States with some form of bankruptcy, specific exemption(s) include both opt-out and non-opt-out jurisdictions. The complexity is exacerbated by uncertainty over whether, in states with comprehensive bankruptcy-specific schemes, these exemptions are exclusive of or in addition to the state's general exemptions. ${ }^{62}$ It is not the purpose of this article to provide an all-encompassing survey of these statutes. Such an exercise would not only fail to advance the main thesis in this study, but would also be of limited utility given the ever-changing nature of the landscape. ${ }^{63} \mathrm{~A}$

\footnotetext{
${ }^{61}$ See Rhodes v. Stewart, 705 F.2d 159, 162 (6th Cir. 1983) (noting that $\$ 522(b)(1)$ represents "an exercise of the legislative prerogative to establish a 'uniform law' and therefore falls within that scope of authority provided to Congress in the Bankruptcy Clause"); In re Sullivan, 680 F.2d 1131, 1135 (7th Cir. 1982); Kosto v. Lausch (In re Lausch), 16 B.R. 162 (M.D. Fla. 1981); In re Butcher, 189 B.R. 357, 370-72 (Bankr. D. Md. 1995); In re Snape, 172 B.R. 361, 363 (Bankr. M.D. Fla. 1994) (concluding that the differences between the former Act and the Code in the designation of property of the estate did not render Moyses inapplicable insofar as the constitutionality of state determined exemptions is concerned). The court in Butcher also rejected the creditor's alternative contention that $\$ 522(\mathrm{~b})$ violates the "Due Process" Clause of the Fifth Amendment, finding that the provision is rationally related to Congress" "legitimate purposes in enacting the bankruptcy laws." Butcher, 189 B.R. at 372. But see Daniel A. Austin, Bankruptcy and the Myth of "Uniform Laws,"42 SETON HALL L. ReV. 1081 (2012) (making the case that the direct incorporation of state law into the Bankruptcy Code violates the bankruptcy uniformity requirement); Koffler, supra note 55, at 87.105 (arguing, based on the original intent of the Framers, that the Moyses doctrine and $\$ 522(\mathrm{~b})$ improperly sacrifice federal policy and predominating national interest to the parochial interests of the states); Tracey Nicolau Bosomworth, Note, Federal Exemptions and the Opt-Out Provisions of Section 522: A Constitutional Challenge, 58 IND. L.J. 143 (1982/83) (asserting that the opt-out alternative in $\S 522(\mathrm{~b})$ represents a marked expansion of the practice under $\S 6$ of the former Act and does not conform with any constitutionally acceptable method for deferring to state law).

${ }^{62} \mathrm{See}$ infra text accompanying notes 85.90 .

${ }^{63}$ Such compilations are available from other sources. See., e.g., supra note 44; 50 State Homestead Exemptions \& Other Bankruptcy Exemptions, LeGALCONsumer.coM, http://www.legalconsumer.com/ bankruptcy/laws/ (last visited June 18, 2014). In Richardson v. Schafer (In re Schafer), 455 B.R. 590, 599 n.10 (B.A.P. 6th Cir. 2011), rev'd, 689 F.3d 601 (6th Cir. 2012), cert denied, 133 S. Ct. 1244 (2013), the BAP identified eight states other than Michigan that have adopted bankruptcy-only exemption schemas. That ignores, however, states, like Kansas and New York, which have taken the approach of augmenting the state's general exemptions for bankruptcy debtor's from those jurisdictions. See infra notes $78-79$ and accompanying text.
} 
few illustrative examples should suffice to provide an overview of the myriad of differing approaches that have been taken, although at least one broad generalization can be made; namely, that, to this point in time, state-enacted bankruptcy-specific exemptions are, overall, more generous to debtors than the states' garden variety judgment-execution exemptions. ${ }^{64}$

The first state to adopt bankruptcy-specific exemptions was Georgia in 1980 - just about one year following the effective date of the Bankruptcy Reform Act of 1978.65 The state's legislature enacted the bankruptcy-specific exemption scheme simultaneously with its action to opt-out of allowing Georgia debtors to claim the federal bankruptcy exemptions. At the time, the Georgia exemptions applicable to debtors in state collection proceedings were, relatively speaking, paltry, although they have been increased in recent years. ${ }^{66}$ By contrast, the Georgia exemptions designed to shield property from administration in a bankruptcy proceeding were much more robust than the generally available exemptions, to a large degree paralleling the Bankruptcy Code's exemptions in $\$ 522(\mathrm{~d}) .67$ The exact reasons for opting-out of the federal scheme, but then adopting a set of bankruptcy-limited exemptions comparable to $\S 522(\mathrm{~d})$, is not altogether clear 68 What is, however, quite apparent is that from the get-go Georgia did not have an issue with debtors being able to protect more property in bankruptcy than could be protected in connection with ordinary judgment execution.

Michigan has always been a non-opt out jurisdiction whose citizens may

\footnotetext{
${ }^{64}$ But see infra notes 66 and 90 (identifying at least one circumstance where the bankruptcy-specific scheme was not as generous as the state's general exemption for the same type of property). See also infra text accompanying notes 193-195 (suggesting that in some instances it may be difficult, if not impossible, to tell if a particular exemption scheme is regularly more or less generous than the state's general exemptions). Finally, the fact that to date bankruptcy-specific legislation largely has been, or at least intended to be, more liberal than the state's non-bankruptcy exemptions is no guarantee that, in the future, a state might decide to discourage its residents from filing bankruptcy by promulgating a mandatory, less generous scheme that applies only in bankruptcy.

${ }^{65}$ Although enacted in 1978, The Bankruptcy Reform Act did not generally become effective on October 1,1979 in order to allow for a sufficient period of transition and so as to coincide with the commencement of a new governmental fiscal year.

${ }^{66}$ The Georgia Constitution provides for a lump-sum cash value exemption of $\$ 1,600$. GA. CONST. art. $1 \S \mathrm{I}$. XXVI. In addition, GA. CODE ANN. $\$ 44-13-1$ now also exempts any real or personal property of a debtor in the amount of $\$ 5,000$, or $\$ 21,500$ for "real or personal property that is the debtor's primary residence." Further, outside of bankruptcy, the cash surrender value of life insurance policies of Georgia debtors are not immune from attachment, whereas the bankruptcy-specific, GA. CODE ANN. $\$$ 44-13100 (a)(9) scheme imposes a dollar limitation on the exemption for the cash value of any unmatured life insurance contract. See In re Joyner, 489 B.R. 292 (Bankr. S.D. Ga. 2012) (holding that the debtors in the case were restricted to the more limited exemption provided for in the state's bankruptcy-specific scheme).

${ }^{67} \mathrm{GA}$. CODE ANN. \$ 44-13-100(a)(1) was amended May 2, 2012, to raise the homestead exemption from $\$ 10,000$ ( $\$ 20,000$ for married couples) to $\$ 21,500$ ( $\$ 43,000$ for married couples).

${ }^{68}$ The aim of preventing joint debtors from stacking exemptions, which accounted for the bankruptcy. specific exemptions in California, may have been a factor. See infra note 76 and accompanying text. Likewise, political pressure from local creditors may have played a hand. See infra note 83 .
} 
claim either the federal bankruptcy exemptions in $\S 522(\mathrm{~d})$ or the state exemptions in $\S 600.6023$ of the Michigan Compiled Laws ("MCL"). Without much by way of explanation, ${ }^{69}$ in 2005, the Michigan legislature adopted a completely new table of exemptions in MCL $\$ 600.5451$ available to: "[a] debtor in bankruptcy under the bankruptcy code, 11 U.S.C. 101 to $1532 \ldots .70$ While there are other important differences between the state's preexisting general exemptions and the new bankruptcy separate exemptions, ${ }^{71}$ the most significant point of departure is between the $\$ 3,500$ home. stead exemption for the debtor's personal residence under MCL $\S 600.6023(\mathrm{~g})$ versus a $\$ 30,000$ homestead exemption $(\$ 45,000$ if the debtor is elderly or disabled) under the bankruptcy-specific statute. ${ }^{72}$

Like Michigan, California has a set of exemptions that are available only to bankruptcy debtors, ${ }^{73}$ but, unlike Michigan, California is an opt-out jurisdiction. Also, unlike Georgia, where one set of exemptions appears by law to pertain in state collections actions and the other in bankruptcy cases, ${ }^{74}$ a California bankruptcy debtor is expressly. given the option to elect between the state's general exemptions or the bankruptcy-only exemptions listed in $\S 703.140$ (b) of the California Civil Procedure Code, subject solely to the limitation that married debtors must rely on the same set of exemptions..$^{75}$ The bankruptcy-only exemptions are more than coincidentally similar to the federal bankruptcy exemptions in $\S 522(\mathrm{~d})$. They are crafted effectively to allow a California debtor the choice between the state and federal bank. ruptcy exemptions, but, because of the limitations requiring joint debtors to elect the same scheme, they prevent joint debtors from maximizing their ex.

${ }^{69}$ See Winnifred P. Boylan \& Melanie R. Byers, The Trek of Michigan Exemptions in the Universe of Bankruptcy, 33 Mich. Real Prop. Rev. 85 (2006) (observing that the charge of the Advisory Commit. tee, formed in response to a request of the Michigan House of Representatives' Civil Law and Judiciary Subcommittee, was to review and provide recommendations to update the property exemption laws, and that there is no explanation as to why the resulting recommendations, ultimately resulting in MicH. Comp. LAws $\$ 600.5451$, focused exclusively on bankruptcy cases). It does, however, seem clear that effort was designed to liberalize exemption policy in the state. See Shapiro v. Sassak (In re Sassak), 426 B.R. $680,688-89$ (E.D. Mich. 2010) (reviewing the legislative history).

${ }^{70} \mathrm{Mich}$. Comp. Laws $\$ 600.5451(1)$.

${ }^{71}$ For a detailed comparison of the respective exemption schemes, see Boylan \& Byers, supra note 69.

${ }^{72}$ Mich. Comp. LaWs $\$ 600.5451(1)(n)$.

${ }^{73} \mathrm{Cal}$. Civ. Proc. Code $\$ 703.140(\mathrm{~b})(2013)$.

${ }^{74}$ See GA. CODE. ANN. $\$ 44-13-21$, which appears to make the bankruptcy and most of the state's nonbankruptcy exemptions mutually exclusive. But cf. infra note 90.

${ }^{75}$ See CAL. Crv. Proc. Code $\S 703.140$ (a) (2013). Unlike in Georgia where the bankruptcy-specific scheme will almost always be more attractive to a debtor than the state's general exemptions, depending on the manner in which the debtor's assets are configured, the bankruptcy-specific schema in California could be less advantageous than the general schema. For example, Cal. Crv. Proc. Code $\$ 704.040$ exempts jewelry, heirlooms, and works of art up to (currently) $\$ 7,625$, whereas the bankruptcy only ex. emptions in $\$ 703.140$ (b)(4) permits an exemption for jewelry up to $\$ 1,525$ in amount, although $\$ 703.140(\mathrm{~b})(5)$ includes a wildcard exemption for any property up to a value of $\$ 1,350$ plus any unused portion of the homestead exemption. 
emptions by engaging in what is known as "stacking"; a practice involving the expansion of exempt property by having each spouse elect to have his or her exemptions determined under different schemas. ${ }^{76}$ Under the Code as originally enacted in 1978, debtors in non-opt jurisdictions could stack exemptions by having one spouse choose the $\$ 522$ (d) exemptions and the other to have his or her exemptions determined by state law. Although the ability to stack exemptions has been foreclosed under the Code since 1986,77 California has retained both its opt-out status and its separate scheme of bankruptcy. only exemptions.

In contrast to all of the previously described state bankruptcy-only statutes is the approach taken in Kansas. ${ }^{78}$ Specifically, in 2011, the Kansas legislature added to the exemptions otherwise generally available to Kansas debtors the right in bankruptcy to also exempt a federal tax refund based on earned income credit (EIC). ${ }^{79}$ In other words, Kansas debtors who file for bankruptcy may, in addition to other state exemptions, exempt their EIC, but Kansas debtors who have not filed for bankruptcy can never protect their EIC from execution by judgment creditors.

The constitutionality of the Kansas statute was unsuccessfully challenged by the trustee in In re Westby. ${ }^{80}$ In the course of the bankruptcy court's decision, Judge Karlin noted that the legislative history to the special exemption in bankruptcy for the EIC suggests that the exemption was adopted in order to enhance the ability of "low income Kansans ... to maintain and improve their lives." 81 She quotes the legislative sponsor of the new exemption as further stating: "Under current law, the debtor can be forced to forfeit

\footnotetext{
${ }^{76}$ The history of, and the legislative intent behind, the confusing statutory scheme in California is recounted in some detail by in In re Lennen, 71 B.R. 80, 81.82 (Bankr. N.D. Cal. 1987).

${ }^{77}$ Code $\$ 522(b)(1)$ was revised by $\$ 306(a)$ of the Bankruptcy Amendments and Federal Judgeship Act of 1983, Pub. L. $98-353,98$ Stat. 333, to provide that joint debtors may not elect to exempt both property described in $\S 522$ (d) and other property described in state or other non-bankruptcy exemption laws.

${ }^{78}$ Kansas is an opt-out jurisdiction, KAN. STAT. ANN. $\$ 60.2312$ (1980), although the state opt-out was amended in 1986 to allow Kansas debtors to also claim as exempt the benefits described in Code $\$ 522$ (d)(10). New York also allows its debtors to claim the general state exemptions, but then adds in bankruptcy the right to up to $\$ 4,000$ in equity in a motor vehicle and various rights to receive payments (or property traceable to certain sources) such as, for example, social security and public assistance benefits, certain retirement plans, a crime victim's reparations law, or a wrongful death suit. N.Y. DeBT. \& CRED. LAW $\$ \S 282,283$ (2011).

${ }^{79}$ Other states, including, Colorado, Nebraska, and Oklahoma, also exempt the EIC, but they do so as part of the general exemption scheme, not in a bankruptcy-only scenario. In other states, the EIC may be exempt as a form of "public assistance."

${ }^{80} 473$ B.R. 392 (Bankr. D. Kan. 2012), affd, 486 B.R. 509 (B.A.P. 10th Cir. 2013). See also In re Earned Income Tax Credit Exemption Constitutional Challenge Cases, 477 B.R. 791 (Bank. D. Kan. 2012) (upholding the constitutionality of the statute), affd, Nazar v. Lea (In re Lea), 2013 WL 4431267 (D. Kan. 2013).
}

${ }^{81}$ Westby, 473 B.R. at 399. 
the [refund of the EIC]. Such forfeiture is counterproductive and further inhibits the debtor's ability to recover, making it more likely that the debtor will come to require state services." 82 Notwithstanding those laudable (albeit somewhat self-interested) goals, Judge Karlin observed that there is no legislative history that explains why the exemption was given to debtors in bankruptcy, but not to general debtors in Kansas outside of bankruptcy, since the rationale for its passage would seem equally applicable in both circumstances. ${ }^{83}$

As observed, while the exemption schemas in California are expressly made mutually exclusive, bankruptcy debtors are permitted to elect to have their exemptions determined under one or the other, 84 whether or not the same thing of a sort is true in Michigan is unclear. In Shapiro v. Sassak, ${ }^{85}$ the trustee challenged the debtor's attempt to claim an exemption based on the state's general exemption statute in addition to the exemptions provided for in the state's list of bankruptcy-only exemptions. Specifically, the trustee maintained that MCL $\S 600.5451$ is the applicable state law when, as was the case here, the debtor elects under $\$ 522(\mathrm{~b})(3)$ to have his exemptions determined by state law rather under than the federal Bankruptcy Code.

The bankruptcy court overruled the objection and the trustee appealed to the district court. The district court's opinion initially observed that, in an unpublished ruling from the bench in an earlier case, ${ }^{86}$ another bankruptcy judge in the same district had sustained such a challenge by the trustee based on the plain wording of the perambulatory language in MCL $\S 600.5451 .{ }^{87}$ In Shapiro, however, Judge Borman declined to follow that authority, noting instead that the available legislative history, together with the context in which MCL $\$ 600.5451$ was adopted, evinced an intention to "modernize and expand" the exemptions available to debtors in bankruptcy, rather than

${ }^{82} \mathrm{Id}$.

${ }^{83} I d$. The same lack of explanation as to why Michigan limited its new exemption scheme in 2005 , see supra note 69 , to debtors who had filed bankruptcy raises some suspicion that perhaps it represents yet another political compromise; one designed to subordinate debtor rights to the interests of powerful local creditors, while favoring debtors at the expense of large national creditors under the bankruptcy law. See Christopher W. Frost, Bankruptcy-Specific Exemptions: Authority, Uniformity, Preemption and Politics, 33 (No. 3) BANKR. L. LTR. 1, 9 (2013). See also infra note 291 In re Wallace, 347 B.R. 626, 632 (Bankr. W.D. Mich. 2006) ("[S]etting bankruptcy policies on the state level would enable states to favor in-state creditors over similarly-situated out-of-state creditors." (quoting Hood v. Tennessee Student Assistance Corp. (In re Hood), 319 F.3d 755, 764-65 (6th Cir. 2003)), abrogated by Richardson v. Schafer (In re Schafer), 689 F.3d 601 (6th Cir. 2012), cert denied, 133 S. Ct. 1244 (2013).

${ }^{84} \mathrm{See}$ supro note 75 and accompanying text.

${ }^{85}$ Shapiro v. Sassak (In re Sassak), 426 B.R. 680 (E.D. Mich. 2010).

${ }^{86}$ In re Eisenberg, No. 05-56811, 2006 WL 7137735 (Bankr. E.D. Mich. Jan. 20, 2006).

${ }^{87}$ Sassak, 426 B.R. at 688 (discussing the bases for the ruling in Eisenberg, including the view that if the legislature had intended to leave existing exemptions available to bankruptcy debtors it would have simply amended MCL $\S 600.6023(a)$ rather than enacted an entirely new chapter). 
to limit them. ${ }^{88}$ The court also suggested that restricting the debtor to the bankruptcy-only exemptions would be to ignore the direction in $\S 522(\mathrm{~b})(3)$ concerning the exemptions to which a debtor is entitled when the debtor elects (or is compelled) to claim her exemptions under state law. ${ }^{89}$ The exclusivity vel non of a comprehensive bankruptcy-specific set of exemptions has created a similar split of authority. in Georgia. 90 As a result, further contributing to the disuniformity in the system produced by the opt-out, it seems that no two state approaches to bankruptcy-specific exemptions can safely be assumed to be alike in all particulars.

\section{CHALLENGES TO BANKRUPTCY-SPECIFIC EXEMPTIONS}

Judge Cole's opinion in In re Schafer ${ }^{91}$ is representative of the weight of more recent authority, including the three other appellate court decisions ${ }^{92}$ on the question of the constitutionality of the various sorts of state bank. ruptcy-specific exemptions. The undisputed facts of the case involved a Michigan debtor's election to have his exemptions determined under MCL $\S 600.5451$ and, as a consequence, enjoy a much larger homestead exemption than he would have enjoyed under either Bankruptcy Code $\S 522(\mathrm{~d})$ or Michigan's general homestead exemption. 93 The trustee objected to the claim as violative of both the Bankruptcy Clause and the Supremacy Clause

\footnotetext{
${ }^{88}$ Id. at 694.

${ }^{89} \mathrm{Id}$. at 691 (construing the Michigan statute consistently with the direction of $\$ 522(\mathrm{~b})(3)$ entitling the debtor to receive all exemptions available under State or local law). See also Sticka v. Applebaum (In re Applebaum), 422 B.R. 684, 690 (B.A.P. 9th Cir. 2009) (suggesting that the decision by Congress to refer to "State and' local law" in $\S 522(\mathrm{~b})(3)(A)$, rather than just "applicable non-bankruptcy law," as it did in $\$ 522(\mathrm{~b})(3)(\mathrm{B})$ (dealing with entireties property) indicates an intent by Congress to empower the states to enact bankruptcy-only exemptions). But see id. at 696 (Markell, J., dissenting) (offering a "simpler, less strained explanation" for the uses of the different phrases).

${ }^{90}$ Compare In re Fullwood 446 B.R. 634 (Bankr. S.D. Ga. 2010) (state statute making workers' compensation claims and payments exempt applied even though the such exemption was not included in Georgia's statute, GA. CODE. ANN. \$ 44-13-100, listing bankruptcy-specific exemptions), with In re Allen, No. 10-50827, 2010 WL 3958171 (Bankr. M.D. Ga. Oct. 4, 2010) (concluding that there is no indication that the Georgia legislature intended to supplement the bankruptcy-specific exemptions in GA. CODE ANN. \$ 44-13-100 with exemptions found in other Georgia statutes). See also In re Joyner, 489 B.R. 292 (Bankr. S.D. Ga. 2012) (holding the bankruptcy-specific exemptions exclusive). The language in GA. CoDE ANN. § 44-13-21 (providing that " $[\mathrm{n}]$ o person who is allowed the exemptions under Code Section 44-13. 100 shall take any benefit under this article; nor shall any person who is allowed the exemptions under this article be allowed the exemptions under Code Section 44-13-100") seems to support the view that the two schemes are mutually exclusive.

${ }^{91}$ Richardson v. Shafer (In re Shafer), 689 F.3d 601 (6th Cir. 2012), cert. denied, 133 S. Ct. 1244 (2013).

${ }^{92}$ Sheehan v. Peveich, 574 F.3d 248 (4th Cir. 2009) (involving a direct appeal based on West Vir. ginia's bankruptcy-only scheme); Kulp v. Zeman (In re Kulp), 949 F.2d 1106, 1109 n.3 (10th Cir. 1991) (discussed infra note 154); Sticka v. Applebaum (In re Applebaum), 422 B.R. 684 (B.A.P. 9th Cir. 2009). See also supra notes 36-37.

${ }^{93}$ See supra text accompanying notes $71-72$.
} 
of the Constitution. In a published decision, ${ }^{94}$ the bankruptcy court rejected the objection, relying heavily on the Sixth Circuit's decision in Rhodes $v$. Stewart, ${ }^{95}$ which had recognized the concurrent authority of the states under the Bankruptcy Code to promulgate laws governing exemptions in bankruptcy cases. 96

On appeal to the circuit's Bankruptcy Appellate Panel ("BAP"), the state of Michigan intervened to support the debtor's position and the enforceability of its statute. The alliance did the debtor very little good, as the BAP reversed the bankruptcy court, finding that: (1) Congress' authority to pass bankruptcy legislation is exclusive, ${ }^{97}$ and (2) MCL $\$ 600.5451$ contravened the Bankruptcy Clause's requirement of geographical uniformity by. creating a disparity between exemptions available to Michigan debtors in and outside of bankruptcy. ${ }^{98}$ As for appellate authority from other jurisdictions reaching the opposite conclusion, ${ }^{99}$ the BAP observed that these decisions had failed to properly distinguish between the debtor's right to exempt property under state law, which is unarguable, from the state's right to enact legislation that applies only in bankruptcy; the latter representing an exercise of power that the BAP concluded was beyond the scope of authority conferred under the opt-out provision of the Code, and, in any case, would be unconstitutional. ${ }^{100}$ The State of Michigan then appealed to the Sixth Circuit, which reinstated the bankruptcy court's judgment in favor of the debtor.

While it has been clear since the early nineteenth century that the states are free to enact bankruptcy laws in circumstances where Congress has not exercised its authority to enact uniform laws on the subject of bankrupt-

${ }^{94}$ In re Jones, 428 B.R. 720 (Bankr. W.D. Mich. 2010).

${ }^{95}$ Rhodes v. Stewart, 705 F.2d 159 (6th Cir. 1983).

${ }^{96}$ Rhodes entailed a constitutional challenge to Tennessee's opt-out legislation on the basis that the Tennessee state exemptions were less beneficial than the exemptions to which the debtor would have been entitled under the Code but for the opt-out. Citing Sturges v. Crowninshield, 17 U.S. (4 Wheat.) 122 (1819) (discussed infra notes 139-141 and accompanying text), the court first noted that it has long been established that the states and the federal government share concurrent authority to promulgate bank. ruptcy laws. Rhodes, 705 F.2d at 163 . The court continued, in somewhat contradictory fashion, that the preemption doctrine could not apply in this case because it involved an area of the law where Congress had "expressly and concurrently authorize[d] the state legislatures to disregard or opt-out of [the federal exemption scheme]." Id. See also supra note 61 for additional citations to cases upholding $\$$ 522(b) and the opt-out based on the doctrine of geographic uniformity adopted by the Supreme Court in Moyses.

${ }^{97}$ Richardson v. Schafer (In re Schafer), 455 B.R. 590, 602 (B.A.P. 6th Cir. 2011) (relying on circuit authority in Hood v. Tennessee Student Assistance Corp. (In re Hood), 319 F.3d 755, 763 (6th Cir. 2003), affd, 541 U.S. 440 (2004), to the effect that the states had ceded their authority to legislate in the area of bankruptcy when the Constitution was enacted).

${ }^{98} \mathrm{Id}$. at 605-06. Having held that the bankruptcy-specific statute violated the Bankruptcy Clause, the court concluded that it was unnecessary to address the Supremacy Clause challenge. Id. at 606-07.

${ }^{99}$ See supra note 92 .

${ }^{100}$ Schafer, 455 B.R. at 604. 
cies, ${ }^{101}$ a condition that existed during most of the nineteenth century, in Shafer the trustee argued that because Congress has adopted a federal bankruptcy law, Michigan's bankruptcy-specific exemption statute violated Congress' exclusive authority in the field. ${ }^{102}$ The trustee, like the BAP, relied heavily on the Sixth Circuit's decision in Hood v. Tennessee Student Assis. tance Corp., ${ }^{103}$ wherein the court had grounded its decision sustaining Congress' authority to abrogate state sovereign immunity in bankruptcy cases on the fact that, when it does act, Congress's authority over the subject of bankruptcies is exclusive. ${ }^{104}$

In his opinion on behalf of the court, however, Judge Cole sought to harmonize Hood with the court's earlier decision in Rhodes. The technique he employed was to focus on the language in $R$ hodes stating that when Congress expressly authorizes the states to act in bankruptcy matters, the states enjoy concurrent jurisdiction with Congress. ${ }^{105}$ The court then observed that $\S 522$ (b) constituted precisely such a ceding of joint authority, thereby conferring on the states not just the authority to have state rather than federal law determine exemptions in bankruptcy, but also the power to act affirmatively with respect to exemptions in bankruptcy, unrelated to applicable state law governing exemption policy for all other purposes. 106

Like the Sixth Circuit's BAP in the decision below, ${ }^{107}$ other courts have not interpreted the opt-out authority in $\S 522(\mathrm{~b})(2)$, and the related incorpo-

\footnotetext{
${ }^{101}$ See infra text accompanying notes 139-140. See also supra note 7.

${ }^{102}$ Richardson v. Shafer (In re Schafer), 689 F.3d 601, 605.06 (6th Cir. 2012), cert denied, 133 S. Ct. 1244 (2013). If, of course, the power is exclusive, then it is also nondelegable. See also infra text accompanying note 175 .

${ }^{103}$ Hood v. Tennessee Student Assistance Corp. (In re Hood), 319 F.3d 755 (6th Cir. 2003), affd, 541 U.S. 440 (2004).

${ }^{104}$ Id. at 764-65 (justifying Congress's abrogation of the states' sovereign immunity pursuant to $\$ 106$ of the Code). This interpretation is a variation of sorts on the dormant commerce clause analysis, but still quite consistent with its underlying analysis of the scope and impact of the powers conferred on Congress by Article 1 of the Constitution. The difference, but not one that offsets the similarities, is that the Commerce Clause represents a bar to state legislation even in the absence of congressional action, see Gibbons v. Ogden, 22 U.S. 1 (1824), while the Bankruptcy Clause reserves exclusive power to Congress only when it has exercised the power, Sturges v. Crowninshield, 17 U.S. (4 Wheat.) 122 (1819).

${ }^{105}$ Schafer, 689 F.3d at 606 ("Under those precedents, the states retain the power to act where the federal government has declined to do so (Hood) or where, as in the area of exemptions, it has decided to permit the states to act (Rhodes)."). Of course, this analysis begs the question of the extent to which Congress has authorized the states to act; the question that goes to the heart of the issue. See Sticka v. Applebaum (In re Applebaum), 422 B.R. 684, 696-97 (B.A.P. 9th Cir. 2009) (Markell, J., dissenting) (carefully examining the legislative history leading to enactment of the Code to conclude that the extent of Congress's delegation to the states was to allow them to choose whether or not their residents would have access to the $\$ 522$ (d) exemptions).

${ }^{106}$ Schafer, 689 F.3d at 607 (citing Sheehan v. Peveich, 574 F.3d 248, 252 (4th Cir. 2009), for the proposition that Congress did not see fit to restrict the authority delegated to the states by requiring that state exemptions apply equally in bankruptcy and non-bankruptcy situations).

${ }^{107}$ Richardson v. Schafer (In re Schafer), 455 B.R. 590, 606 (B.A.P. 6th Cir. 2011) (observing that there is no authority for a state to differentiate among its own citizens).
} 
ration of state law in $\$ 522(\mathrm{~b})(3)$, so broadly. 108 That is to say, to regard those provisions as permitting states effectively to pass exemption legislation not of general applicability within the state, but appertaining only in bank. ruptcy cases filed by or against residents of that state. These courts view the states' opt-out authority as allowing states to avoid the federal bankruptcy exemptions in cases involving their domiciliaries, but not authorizing states to create others in their place. ${ }^{109}$ Similarly, they regard the choice conferred on debtors (subject to the opt-out) under $\$ 522(\mathrm{~b})(3)$ to have their exemptions determined under "State or local law," as falling considerably short of an affirmation of the states' discretion to enact state laws that apply only in bank. ruptcy, ${ }^{110}$ and surely no other provision of the Code or the legislative history can fairly be read as ceding back to the states Congress's exclusive power to adopt bankruptcy legislation.

With regard to the trustee's challenge to the Michigan statute based on the Bankruptcy Clause, the BAP found that the requirement of geographic uniformity, as established by the Court in Moyses, ${ }^{111}$ meant that a state law will be regarded as passing muster on the question of uniformity even though debtors in different states may be treated differently. ${ }^{112}$ In this case, therefore, the BAP had concluded MCL $\S 600.5451$ was infirm in that it precluded the bankruptcy trustee from reaching assets that would be available to a judgment creditor in the same state had bankruptcy not been filed. In other words, the lower court interpreted geographic uniformity as permitting varia. tion from state to state, but mandating that within a state bankruptcy and non-bankruptcy judgment debtors and judgment creditors be treated alike. ${ }^{113}$

On appeal, the Sixth Circuit in Judge Cole's opinion rebuffed this interpretation of uniformity within the Bankruptcy Clause, pointing out that Moyses did not speak to nor require consistency between the treatment of

\footnotetext{
${ }^{108}$ E.g., In re Lennen, 71 B.R. 80,83 (Bankr. N.D. Cal. 1987) (holding that the doctrine of geographic uniformity does not extend to treating debtors from the state differently depending on whether or not they have filed for bankruptcy); In re Reynolds, 24 B.R. 344, 347 (Bankr. S.D. Ohio 1982) (state-enacted bankruptcy-only exemptions invade an area of law reserved by the Constitution to the federal government).

${ }^{109}$ In re Cross, 255 B.R. 25, 34 n.5 (Bankr. D. Ind. 2000). Cross is discussed in greater depth infra text accompanying notes $205 \cdot 213$.

${ }^{110}$ See Sticka v. Applebaum (In re Applebaum), 422 B.R. 684, 695-96 (B.A.P. 9th Cir. 2009) (Markell, J., dissenting) (explaining how $\$ 522$ 's legislative history "leaves no room for doubt that Congress intended to retain states' existing exemption-framing rights, rather than expand them."). Cf. In re Sullivan, 680 F.2d 1131,1137 (7th Cir. 1982) (recognizing that the states' authority to establish exemptions in bankruptcy is permitted only "so long as the state law does not conflict with the federal bankruptcy laws.").

${ }^{111}$ Hanover Nat'l Bank v. Moyses, 186 U.S. 181 (1902).

${ }^{112}$ Schafer, 455 B.R. at 596.

${ }^{113}$ Id. at 596-97 (relying on Moyses, 186 U.S. at 190, and the Supreme Court's later decision in Int'l Shoe Co. v. Pinkus, 278 U.S. 261, 265 (1929), striking an Arkansas statute that provided an alternative state law system governing distribution of the debtor's property and discharge from debts).
} 
debtors and creditors in and outside of bankruptcy. ${ }^{114}$ Citing from its earlier decision in Schultz $v$. United States, ${ }^{115}$ involving the unsuccessful attempt to have BAPCPA's means test declared unconstitutional, the court concluded that geographic uniformity, as established by the Supreme Court in Moyses, ". allows different effects in various states due to dissimilarities in state law, so long as federal law applies uniformly among classes of debtors. ${ }^{n}{ }^{116}$ From this, Judge Cole reasoned that, properly understood, uniformity focuses on the process by which debtors and creditors in the same place are treated, and not necessarily whether the outcomes in and outside of bankruptcy are identical. ${ }^{117}$

Turning to the trustee's Supremacy Clause challenge, Judge Cole expressed the court's concurrence with the analysis in cases from both the Fourth Circuit and the Ninth Circuit BAP addressing the issue. ${ }^{118}$ Specifically, of the three ways in which a state law may be preempted, ${ }^{119}$ the parties had conceded that the first, "express preemption," was not an option in the circumstances. ${ }^{120}$ While of the view that the second form of preemption, field preemption, ${ }^{121}$ was likely inapplicable in relation to federal bankruptcy law as a whole, the court noted that it need not resolve that issue inasmuch as its earlier decision in Rhodes had established that Congress's delegation to the states of an explicit role in the area of bankruptcy exemptions negated the applicability of this form of preemption. ${ }^{122}$ The final question, then, for the

\footnotetext{
${ }^{114}$ Schafer, 689 F.3d at 610 . See also infra text accompany. notes $161-179$ for further discussion.

115529 F.3d 343, 351 (6th Cir. 2008), cert. denied, 555 U.S. 1071 (2008).

${ }^{116} I d$.

${ }^{117}$ Schafer, 689 F.3d. at 611.12 ("Schultz clarified that it is not the outcome that determines the uni-
} formity, but the uniform process by which creditors and debtors in a certain place are treated."). Of course, the challenge to the means test, based on the fact that it calls for calculations determined, in part, on state and county law, attacked Congress's decision to incorporate existing state law. As discussed infra note 188 and text accompanying notes 155.156, 213-216 and 290 that is quite different from Congress effectively acknowledging or acquiescing in the state's ability to pass "bankruptcy laws"; laws that only obtain in bankruptcy cases and have no significance except in that context. That is to say, the issue in Schultz was much more like the issue in Rhodes $v$. Stewart, challenging the use of state exemptions (a long settled matter) than it was like the issue in Schafer-entailing affirmative state legislation in bankruptcy cases.

${ }^{118}$ Sheehan v. Peveich, 574 F.3d 248 (4th Cir. 2009); Sticka v. Applebaum (In re Applebaum), 422 B.R. 684 (B.A.P. 9th Cir. 2009).

${ }^{119}$ See generally Caleb Nelson, Preemption, 86 VA. L. REV. 225, 227.29 (2000) (describing the different forms of express and implied preemption that have been recognized by the Supreme Court).

${ }^{120}$ Schafer, 689 F.3d at 614 . Express preemption applies when Congress, acting within its proper authority, has determined must be regulated by its exclusive governance. See Gade v. Nat'l Solid Wastes Mgmt. Ass'n, 505 U.S. 88 (1992).

${ }^{121}$ See Arizona v. United States, 567 U.S. —, 132 S. Ct. 2492,2500 (2012) (observing "[r]he intent to displace state law altogether can be inferred from a framework of regulation so pervasive ... that Congress left no room for the States to supplement it' or where there is a 'federal interest ... so dominant that the federal system will be assumed to preclude enforcement of state laws on the same subject."').

${ }^{122}$ Schafer, 689 F.3d at 614 (quoting Rhodes v. Stewart, 705 F.2d 159, 163 (1983) to the effect that 
court was whether MCL $\S 600.5451$ was assailable under a "conflict preemption" analysis, which pertains either when it would be impossible to com. ply simultaneously with both the state and federal laws, or compliance with the state law would hinder or frustrate accomplishment in full of the pur. poses underlying the federal law. ${ }^{123}$ Judge Cole rejected the trustee's argument in this regard, noting the seeming absence of conflict, or at most the type of conflict, between MCL $\S 600.541$ and federal law that would be sufficient to trigger preemption. ${ }^{124}$ To the contrary, the court observed that, as-applied, the Michigan statute actually furthers, rather than frustrates, federal bankruptcy policy since it provides for a more favorable homestead ex. emption, consistent with the aim in Chapter 7 of enhancing the debtor's fresh start. ${ }^{125}$

\section{THE CONSTITUTIONAL QUESTIONS}

\section{A. The Bankruptcy Clause and the Requirement of UNIFORMITY}

The origins of the Bankruptcy Clause are obscure. In his classic work, Bankruptcy in United States History, Charles Warren pointed out that the Bankruptcy Clause was not considered by the Federal Convention of 1787 until quite late in the proceedings. ${ }^{126}$ It was then adopted with little discussion or debate. ${ }^{127}$ Nonetheless, a rather clear understanding of the motivations animating the Framers' decision to include the Bankruptcy Clause in

"Congress expressly authorize[d] the states to 'preempt' the federal legislation" with regard to exemp. tions). But see authorities cited infra note 196.

${ }^{123}$ See Perez v. Campbell, 402 U.S. 637, 652 (1971) ("[A]ny state legislation which frustrates the full effectiveness of federal law is rendered invalid by the Supremacy Clause."). Perez involved the attempted withdrawal under an Arizona statute of the debtors' driver's licenses after they had discharged in bank. ruptcy the costs associated with an earlier traffic accident. Id. at 638.44. The majority opinion concluded that the Arizona Motor Vehicle Safety Responsibility Act interfered with the purposes of the discharge as set forth in $\$ 17$ of the Bankruptcy Act of 1898. Id. at 656 .

${ }^{124}$ Schafer, 689 F. 3d at 615 (citing Applebaum, 422 B.R. at 691) (stating that the mere fact that the state-designed bankruptcy exemptions differ from the federal exemptions does not mean that such differences necessarily impede accomplishment of the goals of the federal system).

${ }^{125}$ Id at 616. Accord In re Morrell, 394 B.R. 405 (Bankr. N.D.W. Va. 2008); In re Brown, No. 06. 30199, 2007 WL 2120380 (Bankr. N.D.N.Y. July 23, 2007). But see Applebaum, 422 B.R. at 697 (Markell, J., dissenting) (questioning the "wisdom of relegating the validity of state-enacted bankruptcy-only exemptions to a case-by-case analysis without enunciating any test or guiding principles."); infra text accompanying notes 193-196. The Schafer opinion also distinguished away the Ninth Circuit's decision holding a California statute, purporting to remove property from the bankruptcy estate, unconstitutional under the Supremacy Clause, even though the Michigan statute arguably does precisely the same thing. 689 F.3d at 613 n.6 (discussing Kanter v. Moneymaker (In re Kanter), 505 F.2d 228 (9th Cir. 1974). See also infra note 189.

${ }^{126}$ W ARREN, supra note 6 , at 4.5 (relating that the clause was an addition to Charles Pickney's motion to commit the report on the Full Faith and Credit Clause to the Convention).

${ }^{127}$ Koffler, supra note 55, at 36 (recounting the very limited discussion that occurred at least in the extant records of the Federal Convention.). 
Article I can be gleaned from the Federalist Papers (No. 42), wherein Madison wrote, "The power of establishing uniform laws of bankruptcy is so intimately connected with the regulation of commerce, and will prevent so many frauds where the parties or their property may lie or be removed into different States that the expediency of it seems not likely to be drawn into question."128 There is some thought that by use of the word "bankruptcy" rather than "insolvency," the Framers had in mind the English system of bankruptcy as extant at the time, ${ }^{129}$ which was purely a creditors' remedy with its application limited to merchants and other traders, ${ }^{130}$ but, as Professor Warren observed, "whatever may have been the anticipation of the Framers at the time, the fact is the Bankruptcy Power has developed steadily, from being a regulation of traders for purely commercial purposes, into a National policy of relief, for creditors and debtors of all classes and for the restoration of business .... . ${ }^{n 131}$

While the precise reasons for inclusion of the Bankruptcy Clause, and two other "uniform" provisions, ${ }^{132}$ in Article I may be cloudy, there can be

${ }^{128}$ The Federalist No. 42, at 278 (James Madison) (Isaac Kramnick ed., 1987). Hamilton also urged that the constitutional requirement of uniformity was necessary to prevent each state from prescribing a different rule. The Federalist No. 32 (Alexander Hamilton). Indeed, prior to the American Revolution, there was a dizzying array of colonial laws. See generally Coleman, supra note 5, at 12-13. Exacerbating the situation were the financial strains being experienced in the nation due to obligations incurred during the Revolution and some questionable speculation during the period of the Articles of Confederation. See Bruce H. ManN, Republic of Debtors 175-76 (2002) (discussing the economic situation prevailing in the 1780 s).

${ }^{129}$ Rhett Frimet, The Birth of Bankruptcy in the United States, 96 CoM. L.J. 160, 163.65 (1991) (discussing the English concept of bankruptcy during the Colonial Period at the time). One of the definitive sources on the subject is Professor Levinthal's account of English bankruptcy law. Levinthal, supro note 2 .

${ }^{130}$ Historically, the scope of a bankruptcy law, at least during the period in which the Constitution was written, was to distribute the assets of a debtor among his creditors, and to discharge him from the liability of having his future acquisitions attached at the instance of his creditors for the unsatisfied portion of his debts. An insolvency law, on the other hand, operated upon the petition of the debtor to liberate his person from prison in which he had been confined by the process of State laws for the collection of debts. F. REGIS NOEL, History OF tHE BANRRUPTCY LAW 124 (1919). For a summary of early English Bank. ruptcy Law, see generally Countryman, supra note 50, at 226-27; McCoid, supra note 2; Tabb, supra note 5, at 6-12; Charles J. Tabb, The Historical Evolution of the Bankruptcy Discharge, 65 AM. BANKR. L.J. 325 (1991) (observing how late an arriving phenomenon the discharge is in the broad sweep of English and American bankruptcy law). Professor Warren has observed, however, that the line of demarcation between the two (bankruptcy and insolvency laws) was never as sharp in the Colonies as it was in England, although he speculates that the Framers likely conceived that exercise of the power would primarily be for the benefit of the commercial classes. See WARREN, supra note 6, at 7 .

${ }^{131} \mathrm{Id}$. at 8 . See also Koffler, supra note 55 , at 42 (suggesting that by the time of the very first U.S. bankruptcy law, the focus was on the power of the central government to defeat "the parochial, anticommercial policies of the agrarian states ...., and safeguarding over local interests the nation's interest in establishing and maintaining a single market for the extension of credit).

${ }^{132}$ The power of Congress to establish "an uniform Rule of Naturalization" is contained in the same clause of the Constitution as the federal bankruptcy power. U.S. ConsT. art. 1, $\S 8, \mathrm{cl}$. 4. Likewise, the power conferred on Congress in Article 1 to impose taxes, duties and excises was qualified by the require- 
little doubt that concern and dissatisfaction over the dizzying array of state laws that existed during colonial times and under the Articles of Confederation were unquestionably major considerations in the minds of the Framers, ${ }^{133}$ compounded in all likelihood by the precarious condition of the nation's financial health in the aftermath of the Revolutionary War. ${ }^{134}$ Surely the decision to make explicit in the Constitution the power of Congress to enact uniform laws on the subject of bankruptcies was grounded in significant measure on the dissatisfaction with the fractionalized system of state-only regulation of debtor/creditor relationships that preceded ratification of the Constitution, 135 and continued even afterwards through the 1790 s. ${ }^{136}$ It also seems clear that, from the early days of the Republic, the Bankruptcy Clause was understood to confer broad powers on Congress not only to promulgate laws on the subject of bankruptcy, but also to determine the scope of the states' authority over what sorts of laws constituted a "bank. ruptcy act." ${ }^{137}$ Whatever else might be said in relation to the more limited meaning given to the term "bankruptcies" in 1787 , it is beyond cavil that the Framers recognized that, if not permanently then at least from time-to-time, there would need to be a consistent national response to the issues associated

ment that any such taxes, duties, and excises would be uniform. U.S. CONST. art. I, $\$ 8, \mathrm{cl} 1$. It has been surmised that, at the time, "uniformity" reflected not only a transcending national interest in the subject, but also a concern over the prospect that the federal government might discriminate to favor one state or region over another. See Koffler, supra note 55, at 37-38.

${ }^{133}$ See MANN, supra note 128 , at 80,179 (reviewing the array of different colonial laws, and the fact that, at least in some states, like New York, they changed "with breathtaking frequency. ..."). See also Kurt H. Nadelmann, On the Origin of the Bankruptcy Clause, 1 AM. J. LEGAL Hist. 215, 220.27 (1957) (describing the situation in the colonies and as of the opening of the Constitutional Convention in 1787); supra note 128 .

${ }^{134}$ See MANN, supra note 128 , at 176 . See also Countryman, supra note 50 , at 228 (discussing financial crises at the time). Of course, as Professor Lipson has pointed out, while the confusing, confounding, and fractionalized contemporary state of affairs may explain why the Framers wanted to create a nationwide law on financial distress, they do not necessarily explain why the Bankruptcy Clause took the form it did. See Lipson, supra note 5, at 627 (seeking to advance a constitutional theory of bankruptcy based on the notion of "exceptionalism").

${ }^{135}$ See In re Wallace, 347 B.R. 626, 631 (Bankr. W.D. Mich. 2006) (citing Cent. Virginia Cmty. Coll. v. Katz, 546 U.S. 356, 367.68 (2006) (discussing the backdrop against which the Bankruptcy Clause was adopted)) (noting that the Framers were intent on replacing the hodgepodge of disparate state bankruptcy relief with a single national law that would apply uniformly among all states). See also Koffler, supra note 55 , at $39.40,72.73$ (discussing the use of the uniformity requirement where it appears in the Constitution as a means of overriding sectional interests in an effort to develop a coherent national policy).

${ }^{136}$ Several efforts were made to pass a federal bankruptcy bill in the early years of the new Republic, but all fell prey to sectarian opposition. See generally Thomas Plank, Why Bankruptcy Judges Need Not and Should Not be Article III Judges, 72 AM. Bankr. L.J. 567, 607.08 (1998). See also Randolph J. Haines, Getting to Abrogation, 75 AM. BANKR. L.J. 447, 458 (2002) (noting that Thomas Jefferson, a quite prominent debtor, in particular opposed such laws based on his expressed concern that they would be promerchant and anti-agrarian in orientation, posing the threat of forced sales of bankrupts' lands).

${ }^{137}$ Sturges v. Crowninshield, 17 U.S. (4 Wheat.) 122, 128.29 (1819) (rejecting the older, technical distinction between insolvency and bankruptcy laws). See also supra note 7. 
with financial failures and distress in order to maintain public confidence and avoid precipitating an undesirable "race to the bottom" that might well result from reliance on nonuniform state law. ${ }^{138}$

The Bankruptcy Clause is curious in, and notable for, the fact that the power delegated to Congress by the states is, of course, the power to enact uniform laws on the subject of bankruptcies. In 1819, Chief Justice Marshall addressed the question of whether this reference meant that the laws of bankruptcy were intended to be uniform throughout the country, in which case authority to legislate in the field would need exclusively to be with Congress, or whether the Framers had in mind that Congress would act when it deemed it necessary to establish a uniform system that would preempt inconsistent state law, but that otherwise the states could legislate during periods of dormancy. The Chief Justice concluded that the later interpretation was proper, such that it was only the authority to pass uniform laws in the field that the states ceded to Congress when the Constitution was ratified, and not exclusive authority in the field. ${ }^{39}$ In the absence of a federal bankruptcy law, then, Chief Justice Marshall held that the states

${ }^{138}$ That is to say, bankruptcy law cannot be both uniform and at the same time subject to the legislation of multiple sovereigns. Thus, to the degree that bankruptcy must be uniform, the power to legislate in that area must be exclusively federal. Chief Justice Marshall echoed this theme in his opinion in Ogden $v$. Saunders, 25 U.S. (12 Wheat.) 213, 332 (1827), a case declaring a New York insolvency law that purported to discharge debtors unconstitutional under the Contracts Clause, U.S. Const. art. I, $\$ 10, \mathrm{cl} .1$ (prohibiting the states from impairing the obligation of contracts). In describing the economic environment in which the Constitutional Convention took place, the Chief Justice stated:

The power of changing the relative situation of debtor and creditor . . had been used to such an excess by the State legislatures, as to break in upon the ordinary intercourse of society, and destroy all confidence between man and man. The mischief had become so great, so alarming, as not only to impair commercial intercourse, and threaten the existence of credit, but to sap the morals of the people, and destroy the sanctity of private faith.

Ogden, 25 U.S. (12 Wheat.) at 354-55. While obviously writing sometime after the Convention, Justice Story's Commentaries provide strong support for this view of the Framer's intent. See III Justice STORY Commentaries on the Constitution \$1102, at 7 (De Capo Press ed. 1970) (1st ed. 1833) ('[D]iversities of almost infinite variety and object may be introduced into the local system, which may work gross injustice and inequality, and nourish feuds and discontents in neighboring states.").

${ }^{139}$ Sturges v. Crowninshield, 17 U.S. (4 Wheat.) 122, 196 (1819) ("It is not the right to establish these uniform laws [on the subject of Bankruptcies], but their actual establishment, which is inconsistent with the partial acts of the states."). At the same time, however, the Chief Justice, who was not unfamiliar with the circumstances surrounding the Convention, noted that it was the dissatisfaction of the merchant classes in the years after the Revolutionary War with the with the helter-skelter approach of the various states, and the threat to economic security of the Union that they created, that prompted the Framers to preempt state legislation governing the subject, and to bar the states from interfering with the sanctity of contract. Id. at 205. See also III STORY, supra note 138, $\$ 1102,1104$, at $6-7$, 9. (observing that the justification for the grant of exclusivity was not a mere desire to have one system, but a fear that each state would frame a bankruptcy system that "best suits its own local interests, and pursuits" or that was marked "by undue domestic preferences and favours."); Randolph J. Haines, The Uniformity Power: Why Bank. ruptcy is Different, 77 AM. BANKR. L.J. 129, 170 (explaining that the Chief Justice regarded the grant of 
could pass insolvency legislation, so long as these laws did not violate the Contracts Clause of the Constitution. ${ }^{140}$ The Court did not again speak to the meaning of the "uniform" qualification in the Bankruptcy Clause until the Moyses decision, and its curious determination that the reference was to be understood as relating to geographic and not personal uniformity. ${ }^{141}$

As noted earlier, Moyses involved a challenge to the constitutionality of the Bankruptcy Act of 1898 on the ground that the Act's incorporation of state law exemptions caused it to fail the Article I requirement that federal bankruptcy laws be "uniform." In explicating its holding, the Court stated that $\S 6$ of' the 1898 Act, incorporating state exemptions, was uniform throughout the United States in the constitutional sense of the term because under its provisions the trustee in each state would have access to the same property that would have been available to an executing judgment creditor had bankruptcy not ensued.142 This statement played an important role in the trustee's argument in Schafer, as further discussed below. ${ }^{143}$ The Court in Moyses also rejected the argument that the recognition of state laws in bankruptcy constituted an unlawful delegation by Congress of the legislative power conferred on it by the Constitution on the subject of bankruptcies. ${ }^{144}$ It is important to note, however, that the Court's holding did not extend to the proposition that, under the geographic uniformity test, Congress might incorporate into the federal system a state law that does not apply uniformly to all the citizens of that state, such as legislation only affecting those citizens

power in the Bankruptcy Clause to be not a limitation, but the grant of more extensive power, in Congress).

${ }^{140}$ In this case, the New York law at issue, which provided debtors who surrendered all of their property with a discharge, was found infirm as violating the constitutional interdiction of state laws that impair the obligation of contracts. Sturges, 17 U.S. (4 Wheat.) at 204.

${ }^{14}$ 'Hanover Nat'l Bank v. Moyses, 186 U.S. 181 (1902).

${ }^{142} \mathrm{Id}$. at 188 . It has been contended with some force that the construction of uniformity adopted in Moyses strayed considerably from the intent of the Framers to have a national bankruptcy law that would stand above the partial, clashing undertakings of the states. See Austin, supra note 61, at 1162-64; Countryman, supra note 12 , at 681 ; Koffler, supra note 55 , at 62 . That point aside, however, it is important to recognize, as will be discussed in greater detail below, that the holding in Moyses, that Congress may to an extent defer to state legislation within an otherwise comprehensive scheme of bankruptcy regulation, does not support the view that Congress may also grant the states authority to promulgate bankruptcy legisla. tion-laws that apply only in bankruptcy. See infra text accompanying notes 174, 223-224.

${ }^{143}$ See infra text accompanying notes $160-178$.

${ }^{144}$ Moyses, 186 U.S. at 190 (relying on Wilkerson v. Rahrer, 140 U.S. 545, 561-62 (1891) (sustaining the validity of a congressional act leaving to the states the determination of some fact or state of things, upon which the action of the federal law may apply)). Thus, the court in Moyses, apparently regarded Section 6 of the Bankruptcy Act of 1898 as simply allowing the states to specify the fact or condition of what property the bankruptcy law could operate upon. However, the Court in Rahrer also observed the basic proposition in relation to Congress's Article I powers; namely, that "congress can neither delegate its own powers nor, enlarge those of a State," Rahrer, 140 U.S. at 560, which, it will be argued, is precisely the result of recognizing the validity, if not of general state exemptions, certainly of bankruptcy.only exemptions. See also infra note 175 . 
who file for bankruptcy. ${ }^{145}$ Indeed, the practice was practically unknown until after the enactment of the Bankruptcy Reform Act of 1978.146

The Supreme Court's jurisprudence in relation to the Bankruptcy Clause, while hardly robust, ${ }^{147}$ leaves no doubt that the states retain the authority to pass bankruptcy enactments so long as the federal government has declined to so; that is, when the federal bankruptcy power is dormant, provided that the state law does not impair the obligation of contracts. ${ }^{148}$ That situation, of course has not existed since prior to 1898. In addition, Moyses makes clear that state law may operate in bankruptcy, and frequently does, when Congress determines to delegate certain matters to the states, as it has done since 1898 with the exemption-determining provisions of the Code. ${ }^{149}$

\footnotetext{
${ }^{145}$ Likewise, the case frequently cited along with Moyses, Stellwagen v. Clum, 245 U.S. 605 (1918) (holding that the 1898 Act's application of state fraudulent conveyance law did not violate the Bank. ruptcy Clause) sanctioned Congress's recognition of state law in certain particulars, it did not recognize or approve of a state's authority to enact fraudulent transfer laws that would apply only in bankruptcy cases filed by residents of that state. Indeed, the Court expressly noted in Stellwagen that state laws that conflict with federal bankruptcy law are "suspended." Id. at 610 . This distinction has not been lost to at least some courts under the Code. See, e.g., In re Lennen, 71 B.R. 80, 83 (Bankr. N.D. Cal. 1987) (concluding that bankruptcy-specific exemptions treat debtors who have filed for bankruptcy differently from debtors who have not and, when measured by the "geographic uniformity test [estab lished in Moyses], the exemption scheme ... must fail.").

${ }^{146} \mathrm{Cf}$. Kanter v. Moneymaker (In re Kanter), 505 F.2d 228 (9th Cir. 1974) (invalidating a California exemption statute effective only as against the trustee in bankruptcy). The court in Richardson $v$. Schafer (In re Schafer), 689 F.3d 601, 613 n.6 (6th Cir. 2012), cert. denied, 133 S. Ct. 1244 (2013), sought to differentiate Kanter as entailing an attempt by the state to define "property of the estate," rather than truly as an exemption case. See infra note 189.

${ }^{147}$ The Moyses construct of geographic uniformity has been followed in other Supreme Court decisions. See, e.g., Vanston Bondholders Protective Comm. v. Green, 329 U.S. 156, 172.73 (1946), reh'g dEnied, 329 U.S. 833 (1947) (Frankfurter, J., concurring) ("The Constitution did not intend that transactions that have different legal consequences because they took place in different States shall come out with the same result because they passed through a bankruptcy court."). In only two cases has the Bankruptcy Clause been invoked to invalidate a statute: in one case a federal law and in the other instance a state law. In Railway Labor Executives Ass'n v. Gibbons, 448 U.S. 1301 (1980), the Rock Island Railroad Transition and Employer Assistance Act, 45 U.S.C. $\$ 1005$ (1980), was held to be a bankruptcy statute subject to examination under the Bankruptcy Clause, and not under the Commerce Clause, U.S. CONST. art. I, § 8 , cl. 3; the latter, of course, having no requirement of uniformity. Because this Act was directed effectively toward one railroad, in contrast to Blanchette v. Connecticut General Insurance Corps., 419 U.S. 102 (1974) (where the Act in question applied to all reorganizing railroads within a region), the Court found that enactment of private legislation of this sort violated the Bankruptcy Clause. In International Shoe Co. v. Pinkus, 278 U.S. 261 (1929), the Court invalidated an Arkansas statute that provided an alternative system to the federal bankruptcy law for distribution of the debtor's assets and discharge. The Court observed, "[s]tates may not pass or enforce laws to interfere with or complement the Bankruptcy Act

$\therefore$ Id. at 266

${ }^{148}$ See supra text accompanying note 140 .

${ }^{149}$ The opt-out clause in Code $\$ 522(\mathrm{~b})$, which of course exceeds the Bankruptcy Act's incorporation of state exemptions, has been determined to be a constitutionally permissible exercise of congressional power. See authorities cited supra note 61. It is, however, important not to lose sight of the fact that the opt-out pertains only to $\S 522$ (d); which is to say that the states cannot override other aspects of bank. ruptcy exemption policy. See infra notes 220.224 and accompanying text.
} 
What the high Court's jurisprudence has not yet answered, however, or at least not directly, ${ }^{150}$ is whether this delegation may exceed the incorporation of general state law into the federal scheme, or application of federal law to an existing structure of state-created rights and obligations. In other words, what has not been addressed is whether the state's so-called concurrent power to act in bankruptcy extends to the exercise of a power-enactment of a bankruptcy law ${ }^{151}$ - not prohibited to the states under the Constitution, but also not otherwise possessed by the states when Congress has exercised its preeminent authority in bankruptcy; and a power the very existence of which would seem to clash directly with the concerns that most likely prompted the Framers to grant the federal government control over the nation's bankruptcy laws in the first place. ${ }^{152}$

In the first court of appeals case under the Code to address the issue of whether a state exemption statute that applies only in the case of bankruptcy violates the uniformity requirement in the Bankruptcy Clause, as interpreted by the Supreme Court in Moyses, the Tenth Circuit held that no such infringement existed. ${ }^{153}$ In its cursory discussion in support of this holding, the court offered that no conflict with the federal scheme existed because $\S 522(\mathrm{~b})$ "expressly delegates to states the power to create bankruptcy exemptions." 154 In point of fact, however, the accuracy of this conclusion is open to serious debate. Certainly there is nothing in the language or legislative history of either $\$ \S 522(b)(2)$ or (b)(3) that suggests Congress intended for the states to possess the power to create new exemptions that would apply only in bankruptcy cases filed by their residents. Rather, the states are given authority under $\S 522(\mathrm{~b})(2)$ to deny their residents the opportunity to claim the $\S 522(\mathrm{~d})$ exemptions. Likewise, $\S 522(\mathrm{~b})(3)$ incorporates "State or local law applicable on the date of filing" upon the debtor's election to choose

${ }^{150}$ The Court has, however, left little doubt that ${ }^{~}[\mathrm{t}]$ he fundamental precept of the delegation doctrine is that the lawmaking function belongs to Congress, U.S. ConsT. art. I, $\S 1$, and may not be conveyed to another branch or entity." Loving v. United States, 517 U.S. 748, 758 (1996) (citing Marshall Field \& Co. v. Clark, 143 U.S. 649,692 (1892)).

${ }^{151}$ State-enacted, bankruptcy-specific exemptions are nothing less than that: bankruptcy laws, and it is contended that delegation of such authority, as distinct from either incorporation of state law in the federal system or allowing the states to limit their residents to the state's general exemptions, exceeds the scope of the state's "concurrent jurisdiction" to promulgate bankruptcy laws that the Sixth Circuit originally discussed in Rhodes v. Stewart, 705 F.2d 159, 163 (6th Cir. 1983).

${ }^{152}$ See supra notes $128,133 \cdot 134$ and accompanying text.

${ }^{153}$ Kulp v. Zeman (In re Kulp), 949 F.2d 1106 (10th Cir. 1991).

${ }^{154}$ Id. at 1109 n.3. It is important to note that the principal challenge in this case, which involved a state law exempting certain retirement accounts in bankruptcy, was predicated on whether the statute as properly interpreted applied to the corpus of the account or just the accumulated interest. Therefore, the bulk of the opinion addresses that issue of interpretation. The argument based on the Bankruptcy Clause was raised in the alternative and the court's discussion is limited to a short footnote with very little analysis. Moreover, the court did not address the Supremacy Clause question at all. 
her state exemptions, and of course in opt-out situations, but says nothing about the state's ability to adopt bankruptcy exemptions separate and apart from the state's general exemption laws. ${ }^{155}$ Moreover, as noted, conferring on the states the power to determine affirmatively the property subject to administration in a bankruptcy case, as opposed to simply incorporating the law of the state applicable for other purposes, amounts to delegation of Con. gress's Article I powers in a manner that exceeds the delegation of authority sanctioned by the Supreme Court in Moyses. ${ }^{156}$ The question then becomes whether or not such a delegation is lawful, and on that issue the Tenth Circuit was silent.

By contrast, the BAP's opinion in Schafer tackles the question head-on, leaving no doubt in its estimation that such a delegation would be constitutionally suspect. ${ }^{157}$ Moreover, in construing the uniformity requirement, the court opined that, while a debtor's rights may vary from one state to another without running afoul of the Bankruptcy Clause, the states have no authority to differentiate among their own citizens by creating either property rights or property exemptions applicable only to those citizens who file for bankruptcy. ${ }^{158}$ In concluding that MCL $\S 600.5451$ violates the uniformity prescript of the Bankruptcy Clause, ${ }^{159}$ the court focused specifically on the statement in Moyses that a statute is uniform "when the trustee takes in each state whatever would have been available to the creditor if the bankrupt[cy] law had not been passed." 160

On appeal, ${ }^{161}$ the Sixth Circuit reasoned that the BAP's analysis must fail for three reasons. First, Judge Cole, in his opinion for the court, found that the portion of the Moyses decision that the BAP and the trustee had relied upon to strike MCL $\S 600.54151$ as unconstitutional related to whether

\footnotetext{
${ }^{155}$ Putting aside momentarily the lawfulness of such action, it is has been pointed out that approval of state-created bankruptcy exemptions is not necessarily found either in the language or legislative history of the Code. See supra note 110.

${ }^{156}$ See supra notes $144-146$ and accompanying text.

${ }^{157}$ Richardson v. Schafer (In re Schafer), 455 B.R. 590, 601 (B.A.P. 6th Cir. 2011) ("The Bankruptcy Clause exists to restrict the power of the states to legislate in the area of bankruptcy.").

${ }^{158}$ Id. at 603 (reasoning that while a debtor's rights in one state may vary from the rights of a debtor in a different state, there is no authority for a state to differentiate among its own citizens by creating separate property rights or a separate exemption scheme for only those citizens who file for bankruptcy). The BAP also observed that the Supreme Court's admonition in Butner v. United States, 440 U.S. 48 (1979), that bankruptcy courts should look to state law to determine property interests in the assets of a bankruptcy estate, did not mean that the states had authority to pass legislation that did not apply to all residents, but only those in bankruptcy. Schafer, 455 B.R. at 605 .

${ }^{159}$ Id. at 606 ("A state statute which expressly differentiates between the rights available to a judg. ment creditor and those available to a bankruptcy trustee, violates the uniformity requirements of the Bankruptcy Clause.").

${ }^{160}$ Id. (citing Hanover Nat'l Bank v. Moyses, 186 U.S. 181, 190 (1902)).

${ }^{161}$ Richardson v. Schafer (In re Schafer), 689 F.3d 601 (6th Cir. 2012), cert. denied, 133 S. Ct. 1244 (2013).
} 
Congress could constitutionally defer to the several states nonuniform ex emption schemas in bankruptcy cases, and not whether bankruptcy and nonbankruptcy debtors must be treated alike. ${ }^{162}$ This first rejoinder is questionable on a couple of levels. Initially, the language of the decision in Moyses cited by the BAP represented the holding in the case. It is true that the specific issue before the Court was the validity of the incorporation of state exemptions, but the Moyses' Court's statement upon which the BAP relied relates to the meaning of the term "uniform" in the Bankruptcy Clause, and the application of that explication of "uniform" is in no way limited to a particular context. ${ }^{163}$ In addition, just prior to setting forth its holding, the Court in Moyses cited approvingly from an earlier circuit court decision, In re Deckert, ${ }^{164}$ challenging the constitutionality of the Bankruptcy Act of 1867s' inclusion of state law exemptions in bankruptcy cases. ${ }^{165}$ In that opinion, Chief Justice Waite, writing for the court, observed: "This is not unjust, as every debt is contracted with reference to the rights of the parties thereto under existing exemption laws, and no creditor can reasonably complain if he gets his full share of all that the law, for the time being, places at the disposal of creditors." 166 The implication being that if the property available for creditors is less in bankruptcy than the property liable for judgment execution outside of bankruptcy, then there might indeed be an issue based on the constitutional requirement of uniformity. Finally, the gravamen of the BAP's holding in Schafer was not that debtors and non-debtors "must be treated alike," but rather that uniformity demands that a bankruptcy trustee in the case of a debtor from State X must be treated, for purposes of the property available for administration, the same as other creditors of such debtor would be treated in terms of the property available for judgment execution in State $\mathrm{X}$.

The second reason offered in Schafer for rejecting the BAP's interpretation of the holding Moyses was that that the Moyses Court ultimately con. cluded that its concept of geographical uniformity requires only that the federal law apply uniformly among classes of debtors and, thus, allows for

\footnotetext{
${ }^{162} I d$. at 610 .

${ }^{163}$ See Moyses, 186 U.S. at 190 (the Court's focus was on when the system is uniform in a constitutional sense).

${ }^{164} 7$ F. Cas. 334 (C.C.E.D. Va. 1874) (No. 3,728) (concurring with In re Beckerford, 3 F. Cas. 26 (C.C.D. Mo. 1870) (No. 1,209)). Both decisions have been sharply criticized in terms of the paucity of the constitutional analysis. E.g., Countryman, supra note 12, at 681; Koffler, supra note 55, at 70-71 (sug gesting that the Deckert court erroneously read the term "uniform" to prohibit Congress (as opposed to the states) from impairing contracts, and noting the irony that Moyses should relied on a case that was so clearly wrong).
}

${ }^{165}$ See supra text accompanying note 51.

${ }^{166}$ Deckert, 7 F. Cas. at 336. 
differing effects in various states due to differences in state law. ${ }^{167}$ So conceived, the court held that MCL $\S 600.5451$ applies no less uniformly among classes of debtors than did the exemption scheme upheld by the Court in Moyses. The Sixth Circuit's point seems to be that because $\S 522(\mathrm{~b})$ of the Code, operating in tandem with MCL $\S 600.5451$, treats all Michigan debt. ors who opt to have their exemptions determined under $\$ 526(\mathrm{~b})(3)$ identically insofar as the determination of their exempt property is concerned, there can be no constitutional infirmity. ${ }^{168}$

The difficulty with this analysis is, firstly, that the trustee is not being treated the same as judgment creditors insofar as property available for ad. ministration is concerned, a requirement that seems clearly to be the essence of the holding in Moyses. Secondly, the fact that Michigan debtors, as a class, are treated the same misses the point insofar as the requirement of uniformity in relation to bankruptcy law is concerned. In Butner v. United States, ${ }^{169}$ while recognizing the applicability of state law in defining property interests, the Court emphasized the importance of the uniformity provision in the Bankruptcy Clause, observing that it promotes certainty, discourages forumshopping, and prevents the occurrence of disparate results based merely on the fact of bankruptcy. ${ }^{170}$ Those values are not undermined necessarily by Congress's decision to incorporate the several states' general exemption laws, even if the definition of exempt property will vary depending on which state's exemptions control. But when state legislatures are allowed to, and in fact do, decide that bankruptcy debtors from the state will receive different treatment than judgment debtors from that same state who have elected not to file bankruptcy, then the values underlying uniformity, as articulated by the Court in Butner, are in jeopardy, if not actually already compromised.

Further, the fact that the constitutional requirement of uniformity is "ge. ographic," does not mean that bankruptcy law is uniform simply because it "uniformly" incorporates the laws enacted by each state. Such an interpretation denudes the term "uniformity" of any meaning. ${ }^{171}$ The Framers intended

\footnotetext{
${ }^{167}$ Schafer, 689 F.3d at 610 (citing in support of this proposition the Court's earlier decision in Schultz v. United States, 529 F.3d 343, 353 (6th Cir. 2008), involving an unsuccessful challenge to BAPCPA based on the uniformity requirement in the Bankruptcy Clause).

${ }^{168}$ Presumably, the point also hinges on the assumption that the requirement of uniformity is a limitation on the exercise of federal power only and, therefore, does not apply to the states. See In re Brown, No. 06-30199, 2007 WL 2120380, at *7 (Bankr. N.D.N.Y. 2007). Some courts reject that proposition. E.g., In re Lennen, 71 B.R. 80, 83 (Bankr. N.D. Cal. 1987). More to the point, however, it assumes that the states retain the power to promulgate bankruptcy legislation when Congress has exercised its power to establish uniform laws concerning bankruptcies. This proposition is a dubious one. See supra text accom panying notes $153-156$.

${ }^{169} 440$ U.S. 48 (1979).

${ }^{170} I d$ at 55 .

${ }^{171}$ Surely, such an argument, carried to its logical extreme, would produce results that no reasonable person would seriously abide. For instance, applying the argument to preference law, one could by the
} 
that Congress possess the ability when necessary to effectuate commercial policy at the national level in order to overcome the evils associated with a multiplicity of discordant state laws. ${ }^{172}$ Congress cannot, therefore, properly delegate to the several states the ability to define key features and outcomes in a federal bankruptcy case because the individual states, by definition, do not and cannot affect national policy. Thus, while Congress may constitutionally choose to incorporate aspects of state law into a bankruptcy case, the federal bankruptcy law cannot be considered as operating in a uniform fashion, as constitutionally mandated, when the states are permitted to legislate directly in the federal bankruptcy arena. But that is precisely the effect of state-enacted bankruptcy-specific exemptions; i.e., to legislate bankruptcy outcomes, and control the distribution of assets in bankruptcy between debt. ors and their creditors, not just by means of incorporation of existing state law, but particularly and without regard to any general state purpose.

The response to this second reason implicates the third explanation of fered by Judge Cole in Schafer for rejecting the BAP's analysis on the question of uniformity. Specifically, the opinion notes that the holding in Moyses, if literally applied, would call into question the current scheme in $\S 522$ of the Code in situations where: (1) the state has not opted-out, (2) the debtor elects to have her exemptions determined under $\$ 522(\mathrm{~d})$, and (3) the $\S 522(d)$ exemptions exceed the amount of the otherwise applicable state ex. emptions. ${ }^{173}$ This is true, and it is one of several reasons why it is submitted that the incorporation of state exemptions, whether on a mandatory or permissive basis, should be eliminated regardless of whether or not a decision (even assuming such a decision was actually made by Congress) to delegate authority to enact bankruptcy-only exemptions is lawful. ${ }^{174}$

Insofar as the constitutional requirement of uniformity is concerned, how. ever, there is an important difference in the two situations. The election in $\S 522(\mathrm{~b})(3)$ initially gives every debtor in the nation the same choice; between applicable state or federal bankruptcy exemptions, and the debtor will inevitably chose the scheme most favorable for her, unless applicable state

same reasoning conclude that the federal bankruptcy law meets the standards of uniformity if it allows without discrimination each state to determine what eve of bankruptcy transfers might be recoverable and which might not-as perhaps those to in-state creditors. But that, of course, is patently absurd and renders the decision to place the bankruptcy power in the federal government a nullity in spite of the clear intent of the Framers. See, e.g., Hood v. Tennessee Student Assistance Corp. (In re Hood), 319 F.3d 755, 764 (6th Cir. 2003) (pointing out that the catalyst for the Bankruptcy Clause and the requirement of uniformity was to protect against states adopting bankruptcy regimes intended to favor local interests and pursuits, all to the disadvantage of the interests of creditors from surrounding states and the larger national economy).

${ }^{172}$ See supra notes 128,133 and accompanying text.

${ }^{173}$ Schafer, 689 F.3d at $610 \cdot 11$ (observing that no one would call this result into question or otherwise claim it to be impermissible under the Bankruptcy Clause).

${ }^{174}$ See infra Part V. 
law prohibits its residents from having their exempt property determined under $\$ 522(\mathrm{~d})$. By contrast, when a state adopts a set of bankruptcy-only exemptions, it is affirmatively legislating on the subject of bankruptcy in derogation of the power conferred on Congress in the area, and it is expressly doing so in a manner that produces non-uniform results both intra and interstate. The deferral by Congress to the existing structure of state-created rights is one thing, recognition of the rights and limitations legislated by a state intended to apply only in bankruptcy cases is quite another. ${ }^{175}$ The current legislative scheme in $\$ 522$ simply does not go, and should not be construed as going, that far. ${ }^{176}$

Stated another way, in a non-opt-out jurisdiction, there is not much question which exemption scheme the debtor will elect; i.e., the one most advantageous to her, so as to maximize the property she may retain in order to

\footnotetext{
${ }^{175}$ Specifically, this exceeds the permissible scope of congressional delegation based on the standard set forth in Wilkerson v. Rahrer, 140 U.S. 545 (1891), the decision on which the Moyses court relied to conclude that $\$ 6$ of the former Bankruptcy Act did not constitute an impermissible delegation of author. ity. See supra note 144. Rahrer, involved a challenge to an 1890 act of Congress that made the sale of liquor manufactured in one state and transported and sold in another subject to the laws of the state into which the liquor was imported; a so-called "local option" law. The defendant, a Kansas-based agent for a Missouri company, was charged with a misdemeanor under a Kansas law which prohibited him from selling a pint of whiskey that had been transported to him, along with other inventory, for such purpose by his principal. The defendant urged that the law amounted to an impermissible delegation of Congress's exclusive authority to regulate interstate commerce. Initially, the Court observed that, "[i]t does not admit of argument that congress can neither delegate its own powers, nor enlarge those of a state." Rahrer, 140 U.S. at 560. The Court continued, however, that this did not prevent Congress, in the exercise of its constitutional authority, from applying the laws of a state adopted in the proper exercise of that state's police powers. That is, that Congress had not delegated to the state permission to adopt regulations in an area reserved exclusively to the federal government. Rather,
}

[Congress had] simply removed an impediment to the enforcement of the state laws in respect to imported packages in their original condition, created by the absence of a specific utterance on its part. It imparted no power to the state not then possessed, but allowed imported property to fall at once upon arrival within the local jurisdiction.

Id. at 564. By like reasoning, the decision to allow states to have their already existing exemption schemes apply in bankruptcy cases filed by their residents is qualitatively different from a decision to allow the states to promulgate legislation that operates only in the event of, and only within the parameters, of a federal bankruptcy case. As expressed by the court in In re Cross, 255 B.R. 25 (Bankr. N.D. Ind. 2000), the power to forbid is not the same as the power to create.

Thus, in giving states the ability to opt out of the federal bankruptcy exemptions Congress did not give [the states] the authority to create bankruptcy exemptions. Instead, what the opt-out represents is a Congressional willingness to recognize the generally available exemptions that states have created for their own purposes in bankruptcy proceedings.

Id. at 34 n. 5 .

${ }^{176}$ See In re Reinhart, 460 B.R. 466, 469 (Bankr. E.D. Mich. 2011) (urging that $\$ 522$ (b) should be construed so as to avoid a serious question as to its constitutionality), abrogated by Richardson v. Schafer (In re Schafer), 689 F.3d 601 (6th Cir. 2012), cert. denied, 133 S. Ct. 1244 (2013). 
facilitate her fresh start. But when a state, and particularly an opt-out state, dictates the property that will be exempt from administration in bankruptcy cases brought by its residents, those exemptions will apply 177 even if they do not represent the most generous scheme of exemptions either in an absolute sense or just for that particular debtor at that particular time. ${ }^{178}$ This subverts the constitutional authority given to the federal government to enact bankruptcy laws and, when Congress does legislate in the field, to do so to the exclusion of the states. ${ }^{179}$ While it is true Congress has conferred on the states the ability to deprive their residents of the federal bankruptcy exemptions, and thus to have their exemptions determined via incorporation of existing state law, this is not the same as investing the states with the power to legislate bankruptcy exemptions directly, wholly separate and apart from the general state law exemptions. As long as the Bankruptcy Clause is not dormant, that is the province of Congress alone. In other words, Congress can pass a $\$ 522(d)$, but a state cannot do so without running afoul of the Bankruptcy Clause.

The Bankruptcy Clause, like the two other provisions in Article I of the Constitution requiring uniformity, ${ }^{180}$ was a reaction to the weaknesses and inefficiencies associated with erratic, inconsistent, and potentially discriminatory state law in an area deemed to be clothed, or at least from time-to-time clothed, with a strong national interest and policy considerations that transcend the more local and parochial interests that animate state law. ${ }^{181}$ If, in pursuit of that national interest, Congress deems it necessary or desirable to

\footnotetext{
${ }^{177}$ Subject, of course, to any limiting provisions in $\$ 522$, other than in subsection (d). See infra notes 218-222 and accompanying text for further discussion of the limited scope of the opt-out.

${ }^{178}$ The point being that just because bankruptcy-specific statutes promulgated up to now have, largely, been more generous than the states' exemptions that apply for all other purposes does not mean that in the future a state might, deliberately (or inadvertently in a particular case), adopt legislation that provides the debtor with more paltry exemptions than she would enjoy against routine state law judgment collection and execution. See infra text accompanying notes 190-194.

${ }^{179}$ See supra notes 7, 138-139 and accompanying text.

${ }^{180}$ See supra note 132 . The Supreme Court addressed the uniformity requirement of the federal taxing power, U.S. ConsT. art. 1, $\S 8 \mathrm{cl}$. 1, just two years prior to Moyses in Knowlton v. Moore, 178 U.S. 41 (1900). In that decision, the Court rejected the concept of intrinsic or inherent uniformity in favor of an approach requiring that the taxing clause operate without discrimination among the states even though the impact of the tax might not impact the states with equal or even near equal effect. Id. at 89/106 (focusing on the intent of the Framers). This notion of geographic uniformity requires that the determination of the property subject to a tax be determined purely as a matter of federal law and without variation from state to state. This precludes the idea of a federal tax that adopts state exemptions, the concept of geographic uniformity the Court adopted two years later in relation to the Bankruptcy Clause. At least one commentator has argued with some force that the Court would have done well in Moyses to follow the precedent it had established regarding the meaning of uniformity in 'relation to Congress's Article I powers in Knowlton: See Koffler, supra note 55, at 78.84 ('Tested against the Knowlton doctrine, Moyses' recognition of state exemption laws in bankruptcy makes a mockery of the constitutional command of uniformity.").

${ }^{181}$ See supra note 138 and accompanying text.
} 
integrate some non-uniform aspects of state law, Moyses stands for the proposition that Congress may lawfully do so; the system is still a uniform system. By definition, however, no individual state can assure a uniform system of bankruptcy law. Thus, while uniformity does not require that each debtor be treated exactly the same, it does require uniformity in terms of effectuating the ultimate aims of the federal bankruptcy system; e.g., equity, equality, and fresh start. This is where the federal interest lies and it cannot be achieved if individual states have the ability to legislate distributional consequences in bankruptcy with only, as must necessarily be the case, local rather than national interests in mind.

Indirectly, Judge Cole's opinion in Schafer underscores this point when, as part of the Supremacy Clause analysis, it suggests that MCL $\$ 600.5451$ asapplied actually furthers federal policy by facilitating the fresh start for Michigan bankruptcy debtors because it offers a more generous homestead exemption than the state's general exemption statute. ${ }^{182}$ The structural weakness in this rationale, in addition to its dubious unstated assumption that bankruptcy serves only a single policy, ${ }^{183}$ is that there is absolutely nothing to ensure that state legislation in this field, if permitted, will necessarily be more beneficent to bankruptcy debtors than routine judgment debtors. The possibility of a less (or even ambiguously more) generous bankruptcy. specific exemption scheme leads naturally to consideration of the court's treatment of the challenge to MCL $\$ 600.5451$ based on the Supremacy Clause.

\section{B. The Supremacy Clause and Preemption Analysis}

It will be recalled that the BAP in Schafer, having concluded that MCL $\S 500.6461$ was unconstitutional under the uniformity requirement in the Bankruptcy Clause, did not reach the question of the constitutionality the statute under the Supremacy Clause. ${ }^{184}$ The Sixth Circuit's analysis on that issue, discussed above, ${ }^{185}$ seems generally sound as it relates to express preemption, ${ }^{186}$ and perhaps the first form of implied preemption; i.e., field preemption, although the court largely deferred to earlier precedent on that

\footnotetext{
${ }^{182}$ See supra note 125 and accompanying text.

${ }^{183}$ See supra text accompanying note 98 ; infra note 212 and accompanying text. See also supra note 2. Likewise, because of the discharge in bankruptcy, the consequences of declaring property to be exempt are different as well. See supra text accompanying note 231.

${ }^{184}$ See supra text accompanying note 98 . The bankruptcy court had concluded that there was no preemption issue since the statute did not interfere with the basic objectives of the Bankruptcy Code. In re Jones, 428 B.R. 720, 727.28 (Bankr. W.D. Mich. 2010).

${ }^{185}$ See supra text accompanying notes $120-125$.

${ }^{186}$ Congress may withdraw any power from the state by enacting a statute with an express preemption clause. See Arizona v. United States, 567 U.S. _, 132 S. Ct. 2492, 2500-01 (2012). The history of U.S. Bankruptcy law, at least since 1867 , demonstrates that express preemption does not apply to the determination of property exemptions. Stellwagen v. Clum, 245 U.S. 605, 613 (1918).
} 
question. ${ }^{187}$ While not all courts and judges necessarily concur in this analy. sis, ${ }^{188}$ nonetheless, in all fairness, it seems difficult to support the proposition that federal regulation as to exempt property in bankruptcy is so pervasive that it can be regarded as wholly occupying the field when the federal scheme not only recognizes the possible application of state exemptions in bankruptcy, but actually confers on the states the power to make their general exemptions controlling in bankruptcy cases.

On the other hard, the Shafer court's treatment of the other form of implied preemption, conflict preemption, is somewhat more problematic. Specifically, the court predicated its conclusion that the statute at issue did not interfere with federal bankruptcy policy on the basis that bankruptcy-spe. cific-exemptions were no more likely to frustrate the full effectiveness of the national bankruptcy laws than use of a state's general exemptions, an ap. proach that, the court remarked, has been determined to be "wholly appropriate under existing law." 189 And yet, the argument proves too much, as the court tacitly allows in a footnote where it acknowledges that certain unlimited state exemption laws might indeed undermine national policy but then draws comfort that these situations have been tempered by BAPCPA. ${ }^{190}$ The point, as is addressed below, ${ }^{191}$ is that it is one thing for Congress to determine that a federal rule may turn on how a subject is treated by a state for its own purposes, but quite another to conclude that, in so doing, Con-

${ }^{187}$ See supra note 122. See also Sheehan v. Peveich, 574 F.3d 248, 252 (4th Cir. 2009) (noting that there can be no field preemption where Congress has expressly authorized the states to act in relation to the subject).

${ }^{188}$ See, e.g., In re Regevig, 389 B.R. 736, 740 ("Congress has pervasively defined the exemptions that a state may permit a debtor to claim only in a bankruptcy case, even if they are not generally exempt from creditors outside of bankruptcy. Those are the exemptions defined by Bankruptcy Code $\$$ 522(d). And Congress further specified exactly how a state might make those bankruptcy-specific exemptions available-by not opting out pursuant to Code $\$ 522(\mathrm{~b})(2)$. Where Congress has already defined both the substantive law and the procedure, in a pervasive federal scheme that generally pre-empts State legislation, Congress has occupied the field.") (emphasis added); Sticka v. Applebaum (In re Applebaum), 422 B.R. 684, 694 (B.A.P. 9th Cir. 2009) (Markell, J., dissenting) (discussing the primacy of federal law). See also Lamport, supra note 35, at 606-11 (arguing that the federal government has occupied the field of bank. ruptcy legislation and, therefore, state-enacted bankruptcy-only exemptions are preempted even though they may not be in actual conflict with specific provisions of the Bankruptcy Code)

${ }^{189}$ Schafer, 689 F.3d at 615 (observing that, via $\$ 522$ (b), Congress has already allowed for variations in how states treat bankruptcy exemptions, and this situation would seem no different). The court also distinguished the Ninth Circuit's decision rendered under the former Bankruptcy Act in Kanter v. Money. maker (In re Kanter), 505 F.2d 228 (9th Cir. 1974), on the basis that the statute invalidated in that case, defeasing the trustee of any interest in a prepetition personal injury lawsuit, directly conflicted with the provisions of the Act defining the property of the estate. Schafer, 689 F.3d at 613 n.6. Whether the distinction is as clear as the court endeavored to make it is open to some question. See infra note 226. Also, the constitutionality of the opt-out, while surviving challenge thus far, is not a dead letter. See generally Austin, supra note 61 .

${ }^{190}$ Schafer, 689 F.3d at 615 n.7. See also supra note 31 and accompanying text discussing these changes under the 2005 Amendments.

${ }^{191}$ See infra text accompanying notes $215-217$. 
gress intended (and has the constitutional authority) to relinquish its explicit power to determine the contours of the rule and how it shall operate.

In addition to the failure to find a distinction between the use of a state's general exemptions and a bankruptcy-specific exemption schema, Judge Cole, as noted above, ${ }^{192}$ also pointed up that MCL $\S 600.5451$ actually furthers rather than conflicts with federal policy in the field since it expands a debtor's fresh start. The clear but unstated implication is that if a state-enacted bankruptcy-specific exemption scheme made a bankruptcy debtor's exemptions less generous than those enjoyed by judgment debtors in the state generally, the court would strike it based on conflict preemption. Even if true, the problem with this approach is two-fold; practical and doctrinal.

First, a bankruptcy-only exemption, scheme, even if clearly mandated under state law, may not be definitively or consistently either more or less generous than the state's regular list of exempt property or assets. ${ }^{193}$ This could arise because the scope of the exempt property is less under the bankruptcy-only scheme, but the dollar amounts for the actual exemptions are higher than under the state's general exemptions. Alternatively, the bankruptcy statute could be more generous in terms of the categories of property defined as exempt, including perhaps a wildcard, but less generous in one or more of these categories of property in terms of the dollar limitation. In effect, each debtor's particular circumstances at any given point in time would dictate if the bankruptcy exemption scheme were more or less generous. Thus, there would be no way to say categorically whether the state's bankruptcy-only exemption scheme furthered or frustrated the debtor's fresh start since, as a practical matter, it would intrinsically do neither (or both) on a consistent or predictable basis. ${ }^{194}$ In short, just because most bankruptcyspecific state laws appear (and may have been intended) to favor debtors, does not mean they will always do so, ${ }^{195}$ or that if and when they do the

\footnotetext{
${ }^{192}$ See supra note 125 and accompanying text.

${ }^{193}$ The fact that the exclusivity of such statutes in adopting states is unclear only exacerbates the uncertainty and creates another level of confusion regarding the effect of such laws. See supra text accompanying notes $85 \cdot 89$.

${ }^{194}$ This is just one of perhaps several problems associated with dealing with state-promulgated bankruptcy-only exemptions on a case-by-case basis, rather than by prophylactic rule. See supra note 129.

${ }^{195}$ As an example where a bankruptcy-specific statute was more restrictive than the general exemption, and yet sustained in spite of both the Uniformity and the Supremacy Clauses, see In re Joymer, 489 B.R. 292 (Bankr. S.D. Ga. 2012) (holding that Georgia's bankruptcy-specific exemption scheme, which permitted Georgia debtors who had filed for bankruptcy only a limited exemption in cash surrender value of life insurance policies and not the broader exemption in such cash surrender values accorded to Georgia debtors outside of bankruptcy, did not violate the Equal Protection Clause of the Georgia or United States Constitutions, since it was rationally related to differences that existed between policyholders seeking to discharge all of their prepetition debts in bankruptcy and policyholders who were not in bankruptcy and, presumably, paying all their legitimate obligations).
} 
inquiry is necessarily at an end. ${ }^{196}$ Moreover, an approach to conflict preemption that focuses only on conflict with the fresh start doctrine overlooks the fact that the purpose of the federal bankruptcy law is not wholly confined to providing a fresh start for debtors; rather, bankruptcy policy seeks to accommodate the interests of creditors as well as debtors. ${ }^{197}$

Second, in the paragraph in Schafer just preceding the paragraph in which Judge Cole discusses the impact of MCL $\S 600.5451$ on an as-applied basis, he seems to negate the argument that a less generous state bankruptcy ex. emption scheme might be constitutionally invalid. Specifically, in rebuffing the trustee's argument that a more generous set of bankruptcy-only state exemptions might operate as a disincentive to creditors that have reason to and might otherwise be inclined to file an involuntary petition, the court states that " $\$ 522$ imposes no restrictions on the concurrent authority of the states to enact bankruptcy-specific exemption statutes. We will not read any such restriction into another section of the Code, such as $\S 303$, that has nothing to do with exemptions." 198 If no restriction on the concurrent authority of the states is to be found in $\S 522$ or elsewhere in the Code, then the conclusion ineluctably must be that the states have carte blanche in forg. ing their exemption schemas, despite the fact that they might conflict with, or at least hinder the attainment of, the purposes and objectives of the federal bankruptcy law. And yet, it is hard to imagine that this could be so and not compromise the Supremacy Clause. ${ }^{199}$

In sum, it is not a question of whether any particular bankruptcy-only statute operates at any particular point in time to undermine fundamental bankruptcy policy. ${ }^{200}$ Rather, it is the risk that such legislation can, in both easily detectable and far less palpable ways, have such an impact from timeto-time that is crucial to the preemption analysis. The bankruptcy court in In re Cross ${ }^{201}$ seemed to apprehend and articulate the point most clearly. The case involved an Indiana statute that permitted an exemption in bank.

${ }^{196}$ See In re Regevig, 389 B.R. 736, 740 (Bankr. D. Ariz. 2008) (citing Sherwood Partners, Inc. v. Lycos, Inc., 394 F.3d 1198, 1203.06 (2005) for the proposition that a showing of actual prejudice in the case at hand is not necessary to support a challenge based either on the Bankruptcy or the Supremacy Clause). Likewise, a state statue cannot be sustained on the basis that the legislature did not intend to frustrate the operation of federal law. See Perez v. Campbell, 402 U.S. 637, 651-52 (1971) (rejecting the view that frustration should be measured solely by the purpose of a state law and not necessarily its effect).

${ }^{197}$ See infra text accompanying notes 211-213; supra note 2 and accompanying text

${ }^{198}$ Schafer, 689 F.3d at 616.

${ }^{199}$ If not, then the whole purpose behind the Bankruptcy Clause of overriding the shortcomings of the Articles of Confederation and curbing the potential for states' abuse of power in the arena of debtor/ creditor relationships would be relegated to oblivion. See supra notes 133.134 and accompanying text.

${ }^{200}$ See supra text accompanying notes 193-194, 196.

${ }^{201} 255$ B.R. 25 (Bankr. N.D. Ind. 2000). 
ruptcy for a debtor's interest in property held as a tenant by the entireties, ${ }^{202}$ even though outside of bankruptcy Indiana law allows entireties property to be used to satisfy the claims of joint creditors (of the tenants), albeit not the claims of individual creditors of either tenant/spouse. The debtor in this case relied on that statute to assert entitlement to an exemption for certain real property owned by him and his nondebtor spouse as tenants by the entireties. The trustee objected to the exemption on the ground that the Indiana statute was unconstitutional since it prevented him from reaching and ad. ministering assets that, outside of bankruptcy, could be reached at least to some extent by the debtor's creditors. ${ }^{203}$

Relying on Moyses, the court initially rejected the argument that the statute was infirm based on the uniformity requirement in the Bankruptcy Clause. ${ }^{204}$ With regard to the preemption argument, however, the trustee found a much more sympathetic audience. The court began its analysis by observing that the determination of where the balance should be struck between the interests of debtors and creditors goes to the heart of the bank. ruptcy process and is an exercise that has been consigned to Congress alone. 205 Thus, the court continued, a state law that might alter that balance in the event of bankruptcy, as contrasted with a decision by Congress to recog, nize a state-created right or nonbankruptcy entitlement, interferes with national policy in two respects: (1) changing the way Congress chose to allocate the consequences of bankruptcy between debtors and creditors, ${ }^{206}$ and (2) conflicting with the statutory framework Congress created for dealing with entireties property in a bankruptcy case filed by only one spouse. ${ }^{207}$ To illustrate its point, the court in Cross hypothesized, at the antipodal extremes, that a state might either pass a law eliminating all exemptions for bankruptcy debtors or enact a law exempting all of the debtor's property upon filing. In either case, whether, respectively, eroding or enhancing the fresh start (and

${ }^{202}$ The statute, IND. CODE $\S 34 \cdot 2 \cdot 28 \cdot 1$ (a)(5), provided an exemption for any interest in real estate held by the debtor as a tenant by the entireties as of the date of filing for relief under the Bankruptcy Code, unless the case was filed as a joint petition, which was not the case in Cross.

${ }^{203}$ Cross, 255 B.R. at 32.

${ }^{204}$ Id. at 31 (holding that since the "Uniformity Clause" does not apply to the states, the state statute could not be challenged directly or indirectly under the constitutional provision giving Congress the power to establish uniform laws on the subject of bankruptcies).

${ }^{205}$ Id. at 32-33 (noting that while one might question or even disagree with how Congress has resolved the tension between these competing interests, "it was Congress's right to make those decisions and the states cannot change the balance that Congress has struck.").

${ }^{206}$ Id. at 36 (observing as well that Indiana is free to create whatever exemptions it wishes, or none at all; but what it may not do is create (or deny) exemptions solely by reason of bankruptcy). The court went on to note that the effect of the Indiana statute is to treat trustees less favorably than judgment creditors outside of bankruptcy in violation of the Supremacy Clause. Id.

${ }^{207}$ See Code $\$ 522(\mathrm{~b})(3)(\mathrm{B})$ dealing with property held as tenants by the entireties where only one of the tenant-spouses seeks relief in bankruptcy. 
simultaneously increasing or decreasing payment to creditors), the state would quite obviously be improperly interfering in an area of the law that the Constitution assigns exclusively (when it chooses to act) to Congress and, thus, hindering the full accomplishment of the purposes underlying the Bankruptcy Code. ${ }^{208}$

The key take-away from Cross is that it largely does not matter what any particular bankruptcy-specific statute does or does not do; whether it enhances or frustrates the fresh start. Nor does it matter that no state is likely to adopt either of the extreme examples set forth in Cross and thereby radically alter the balance between a debtor and her creditors by making all or none of her property exempt in bankruptcy. Rather, as the court put it in Cross: "[i]f it is permissible for the states to meddle with federal law in small ways, they may also do so in more significant ways. ... [they] may either interfere with federal law or they may not." 209 The court also addressed the argument raised by another bankruptcy court, ${ }^{210}$ and that would later be raised again by the Sixth Circuit in Schafer, ${ }^{211}$ that a state law that provides more favorable exemptions to a bankruptcy debtor than those otherwise available under state law is not assailable under conflict preemption since it actually fosters rather than frustrates bankruptcy policy by enhancing the debtor's fresh start. The court in Cross rejected the argument as too simplistic, since it necessarily focuses on only one of several competing objectives that the bankruptcy system seeks to attain. ${ }^{212}$ This observation underscores the fact that ascertaining whether a state law advances or hinders bankruptcy policy is an inexact science fraught with the risk of miscalculation to begin with ${ }^{213}$; a risk that is exacerbated by the fact that bankruptcy policy is neither static nor monolithic. This is why the power to make bankruptcy

${ }^{208}$ Cross, 255 B.R. at 34-35. The latter scheme would likely fail under the Contracts Clause as tantamount to a state-granted discharge. See supra note 138 .

${ }^{209}$ Cross, 255 B.R. at 35.

${ }^{210}$ In re Vasko, 6 B.R. 317 (Bankr. N.D. Ohio 1980) (sustaining an Ohio bankruptcy.only exemption).

${ }^{211}$ See supra notes 125,189 and accompanying text.

${ }^{212}$ Cross, 255 B.R. at 35-36. The Cross court pointed out that the Vasko decision sustained the statute in question since it furthered federal fresh start policy, but neglected to recognize and take into account that bankruptcy also seeks to assure maximization of value for creditors. See also Stellwagen $\mathrm{v}$. Clum, 245 U.S. 605,616 (1918) (explaining the federal system of bankruptcy is designed to assure the fair and equitable treatment of creditors as well as aid the unfortunate debtor by providing her with a fresh start). The point to be made is that this delicate balance, once struck by Congress, can only be tottered once the states are permitted to pass legislation affecting it, regardless of the motivation underlying such legislation. Cross 255 B.R. at 38.

${ }^{213}$ See supra text accompanying notes 193-196. See also In re Regevig, 389 B.R. 736, 740 (Bankr. D. Ariz. 2008) (pointing out that a challenge to a statute based on either the Bankruptcy or the Supremacy Clauses does not require a showing of actual prejudice arising from application of the statute in the case at hand). 
laws rests with Congress, and it is a power that when exercised must operate to the exclusion of the states.

Notwithstanding the decision in Cross, and other similar cases, ${ }^{214}$ the growing judicial approbation of the notion that, regardless of where Congress decides to place the normative fulcrum in terms of balancing the interests of debtor relief and creditor rights, the states can alter the distributional consequences of bankruptcy by promulgating legislation that applies only in bankruptcy cases raises serious concern. Of necessity, this not only potentially undermines congressional decision making in a manner that ought to be regarded as suspect under ordinary principles of federalism, but also does so in the face of Congress's constitutional preeminence to determine national policy in the area. ${ }^{215}$ While one might fairly question, as I do, ${ }^{216}$ Congress's decision to allow the states to bar their citizens who file bankruptcy from claiming the $\S 522(\mathrm{~d})$ exemptions, that is quite different from concluding that Congress may, and indeed has, delegated to each state the power to control and define the scope of exemption policy in bankruptcy, wholly apart from the policy judgments that underlie that jurisdiction's rules relating to property exempt from routine judgment collection efforts.

It is certainly true that the case law approving the states' prerogative to promulgate bankruptcy-specific exemptions under $\$ 522(\mathrm{~b})$ appears at least to place some limits on that authority; to wit, reserving the right to strike any such law if its application is found to interfere with full attainment of the purposes and objectives of the Bankruptcy Code ${ }^{217}$ The lack, however, of any guidance as to the means and method by which that not insubstantial determination is to be made suggests that little comfort ought to be derived from that caveat. ${ }^{218}$ The issue is not simply striking a state statute that, as

${ }^{214}$ See supra note 35 .

${ }^{215}$ This might occur, for example, by giving the state's debtors a head start at the expense of national creditors more likely to be affected by a bankruptcy filing. This is why, as the court in Cross understood, recognizing state exemptions in bankruptcy as a matter of federal determination is not the same as allowing states to create exemptions just for these proceedings. Cross, 255 B.R. at 34. See also Regevig, 389 B.R. at 741 (holding that there is "no room for states to adopt their own bankruptcy-specific exemptions by a procedure other than that provided by the Code, i.e., not opting out of the Bankruptcy Code's exemptions.").

${ }^{216}$ See infra Part V.

${ }^{217}$ See, e.g., In re Westby, 473 B.R. 392, 413 n.147 (Bankr. D. Kan. 2012), affd, 486 B.R. 509 (B.A.P 10th Cir. 2013) ("Of course, the Court can imagine scenarios where a state enacts an exemption scheme so contrary to the bankruptcy fresh start or the ratable distribution of assets that the exemptions conflict with the purpose and objectives of the Bankruptcy Code. That scenario is simply not present here.").

${ }^{218}$ See supra text accompanying notes 193-196 (addressing the potential difficulty in ascertaining whether any particular statute in any particular case does or does not interfere with achievement of the full objectives of the Bankruptcy Code). In his dissenting opinion in Sticka v. Applebaum (In re Applebaum), 422 B.R. 684, 693 (B.A.P. 9th Cir. 2009), Judge Markell warned that, even if the majority's interpretation of $\S 522(\mathrm{~b})$ to permit incorporation of state-enacted exemptions was correct, having the 
Judge Cole stated, "frustrates" rather than "furthers" the fresh start policy, ${ }^{219}$ such as, to use the extreme example offered by the bankruptcy court in Cross, a state law providing that the debtors from that state shall not be entitled to exempt any property in bankruptcy. 220 Rather, the issue is how, on a principled and consistent basis, to identify and draw an unambiguous distinction between those exemption statutes that "further" and those that (or might) "frustrate" not just the fresh start policy, but also the competing objectives sought to be served by the federal bankruptcy law. The short answer is that it cannot be done.

There are also any number of other instances where a state-enacted bank. ruptcy-specific exemption rule would doubtless be impermissible. For instance, as noted earlier, in order to preclude their debtors from stacking exemptions in jointly administered cases, ${ }^{221}$ some states opted-out of the federal exemptions, but then proceeded to adopt their own very similar bank. ruptcy exemptions. And, yet, because the Code was later amended to ex. pressly prohibits stacking, ${ }^{22}$ a non-opt state, even though wishing to further the federal fresh start policy, could not now pass a law that permitted spouses to stack exemptions by allowing each to elect a different set of ex. emptions. Similarly, a state statute that recognized in bankruptcy a waiver of exemptions in favor of unsecured creditors would never be tolerated. ${ }^{223}$ This highlights the fact that "delegation" to the states of authority to opt-out of the federal exemptions should not reflexively be considered as a wholesale delegation to the states of authority, or an abnegation of federal control, over exemption policy in bankruptcy. Section 522(b)(2) does not grant the states

validity of statutes analyzed on a case-by-case basis, with no underlying guidelines was of questionable wisdom. Id. at 697 .

${ }^{219}$ Schafer, 689 F.3d at 616.

${ }^{220}$ See supra note 208 . Rarely will the situation ever be this obvious, and the uncertainty over where to draw the lines is itself damaging to the system as it imposes a cost of uncertainty. Surely, the proponents of allowing the states this authority will argue how is this any different from a state eliminating exemptions across the board, not just in bankruptcy? See Schafer, 689 F.3d at 614-15. In one sense, it is not; in the unlikely event the state legislature has the political will to take such action. However, in that situation, the state would not be discriminating between bankruptcy and nonbankruptcy debtors, a situation never contemplated by the opt-out, and compromising bankruptcy policy in the process. Moreover, in that situation, Congress might eventually react, just as it has in the case of the states like Florida and Texas that went the other direction with respect to the homestead, and limit the extent of state incorporation by, for example, allowing use of some or all of the $\$ 522(\mathrm{~d})$ exemptions in those situations. See supra text accompanying notes 28.31 . In any case, the issue is not whether the debtor is denied any exemptions, but rather whether the debtor is denied any exemptions because of Congress' decision to recognize state law of general applicability. That's quite different from a debtor being denied any exemptions because the state has denied its citizens certain rights that they enjoy outside of bankruptcy. And, of course, the same can be said about the state creating rights that apply only in bankruptcy.

${ }^{221}$ See supra notes $76-77$ and accompanying text.

${ }^{222}$ See Code $\$ 522(\mathrm{~b})(1)$, as to which the states have no authority to "opt-out."

${ }^{223}$ See Code $\$ 522(\mathrm{e})$; supra note 177 and accompanying text. 
anything even approaching that degree of autonomy. ${ }^{224}$ Rather, the delegation must be understood as limited not only by its explicit terms (i.e., the ability to deny residents access to the federal exemptions), but also by the parameters that defined core bankruptcy policy. Thus, as bankruptcy-only exemptions were for all intents and purposes unknown when Congress adopted the opt-out provision, ${ }^{225}$ it is fanciful to regard its enabling authority as extending to permission to enact bankruptcy-specific legislation, ${ }^{226}$ even to the extent such a delegation would be constitutionally permissible in the first place.

\section{MANDATORY FEDERAL BANKRUPTCY EXEMPTIONS, THEN AND NOW}

\section{A. The Opt-Out Revisited}

The fact that the exemptions available to a debtor in bankruptcy have historically served as a proxy for battles over issues other than the optimal level of property necessary, given the competing interests of creditors, to best effectuate the debtor's fresh start has hampered the development of a rational approach to exemption policy in bankruptcy. By definition, that policy is not identical with the policy governing exemptions from judgment execution. As earlier noted, ${ }^{227}$ the question addressed by state law is what property (or what property up to a particular dollar value), while held in a particular form, should be exempt from execution by judgment creditors? In bankruptcy, on the other hand, the question is how much property is reasonably necessary to facilitate the debtor's return to economic viability - regardless of what justification one accepts of the reason for offering a fresh start in the first place ${ }^{228}$ - taking into account the fact that the debtor is being absolved from future liability for all but a handful of debts that either were the product of opprobrious debtor conduct or implicate competing interests that trump the discharge. ${ }^{229}$ Indeed, one view of the fresh start is that the debtor's nonex.

\footnotetext{
${ }^{224}$ See TABB, supra note 31 , at $\$ 9.2$, p. 870 . (observing the importance of taking note that the opt-out applies only to the ability to claim the $\$ 522$ (d) exemptions and does not apply to the rest of $\$ 522$ ).

${ }^{225}$ See supra note 146.

${ }^{226}$ See Owen v. Owen, 500 U.S. 305, 313 (1991) ("We have no basis for pronouncing the opt-out policy absolute, but must apply it along with whatever other competing or limiting policies the statute contains."). See also Sticka v. Applebaum (In re Applebaum), 422 B.R. 684, 694-95 (B.A.P. 9th Cir. 2009) (Markell, J., dissenting) (arguing that state-enacted bankruptcy-only exemptions thwart the federal bankruptcy scheme) (relying on Kanter v. Moneymaker (In re Kanter), 505 F.2d 228, 230-31 (9th Cir. 1974), a Bankruptcy Act case in which the court held that a state statute that deprived the trustee, and only the trustee, of assets that could be reached by general creditors violated the Supremacy Clause, inasmuch as the decision to recognize state exemptions did not mean that Congress was providing the states with a "free hand to circumseribe the powers of the bankruptcy trustee.").

${ }^{227}$ See supra text accompanying notes 12-13; Applebaum, 422 B.R. at 694-95 (Markell, J., dissenting).

${ }^{228}$ See supra note 1.

${ }^{229} \mathrm{See}$ Ponoroff, supra note 4, at 2555 (discussing the fact that the presumption is in favor of discharge,
} 
empt assets are being surrendered in return for a discharge. ${ }^{230}$ This would, for instance, make an unlimited homestead exemption, that might be justified under state law (since the value of the residence cannot be used for other purposes without exposing it to execution by creditors), suspect in bankruptcy. By the same token, however, failure to provide debtors with a meaningfully adequate quantum of property frustrates national fresh start policy, but that is precisely a possibility permitted under the Code's current chaotic approach to exemptions. ${ }^{231}$

In sharp contrast to state collection law, bankruptcy also seeks to maximize value for creditors as a whole, and to promote equality among similarly positioned creditors. The latter objective is, however, subject to any number of exceptions in specific instances where other policy considerations are regarded as paramount. The categories of debt entitled to priority under $\$ 507$ represent a notable example of this on-going balancing exercise. Focusing on this fact, in a recent article, ${ }^{232}$ Professors Mark Roe and Fredrick Tung argue that bankruptcy is not the static, contractarian institution that dominated much of the earlier thinking about bankruptcy by theorists who share with them an economic-based approach to the subject. ${ }^{233}$ Rather, they maintain, it is a dynamic process that is rife with rent-seeking behavior, the costs of which tax the efficiency (costs of uncertainty) of the bankruptcy process. Creditors constantly invent new transactions, they point out, pursue new court doctrines, and lobby legislatures for new rules that yield them higher priority. ${ }^{234}$ Of course, an alternative way to view the behavior that Roe and Tung in the main condemn as contrary to the efficiency of a purely contractarian model ${ }^{235}$ is as the inevitable by-product of a system that seeks

though certain categories of debt are then excepted, based either on conduct surrounding the incurring of the debt or in order to serve other societal interests that compete with the fresh start).

${ }^{230}$ See Stellwagen v. Clum, 245 U.S. 605, 617 (1917) ("The federal system of bankruptcy is designed not only to distribute the property of the estate, not by law exempted, fairly and equally among his creditors, but as a main purpose by giving him a fresh start in life... Our decisions lay great stress upon this feature of the law ... in that it secures to the unfortunate debtor, who surrenders his property for distribution, a new opportunity in life."). See also Mooney, supra note 1, at 1047 ("Offering a discharge as a tool for inducing debtor cooperation also was a justification advanced for the Bankruptcy Act of 1800 in the United States. And this concept continues to play a role in the availability of a discharge under current law.").

${ }^{231}$ See supra notes $28-31$ and accompanying text.

${ }^{232}$ Mark J. Roe \& Frederick Tung, Breaking Bankruptcy Priority: How Rent-Seeking Upends the Creditors' Bargain, 99 VA. L. REV. 1235 (2013).

${ }^{233}$ The genre dates back to Tom Jackson's "creditors' bargain" normative account of bankruptcy law. See generally Thomas H. Jackson, Bankruptcy, Non-Bankruptcy Entitlements, and the Creditors' Bargain, 91 YALE L.J. 857 (1982).

${ }^{234}$ Roe \& Tung, supra note 232 , at $1270-72$. The authors fashion their understanding as "dynamic creditor bargains, ${ }^{n}$ as creditors continually strive to alter the existing priority framework by changing the rules in their favor.

${ }^{235}$ The authors concede that some of the changes to priority and distribution rules occasioned by rent. 
simultaneously to accommodate multiple goals and objectives that are not always complementary, and at times even antithetical. ${ }^{236}$ And yet, this is precisely the role that a system of federal bankruptcy laws occupies, and one that could only be occupied at the national level, as the Framers well knew and understood. ${ }^{237}$

The Code's unfortunate opt-out compromise has undoubtedly weakened the achievement of these unique goals of federal bankruptcy law. Even more insidiously, however, because of its amenability to what likely amounts to a more expansive interpretation than it deserves, ${ }^{238}$ it has also spawned the current constitutional uncertainties surrounding bankruptcy-only exemptions. As the discord in the case law amply attests, these constitutional questions are hardly trifling. They are, however, easily avoided. Indeed, the fact that, in the main, bankruptcy-specific exemption statutes are not less generous than the general exemption schemas in the states that have adopted them-thereby averting what could be a successful preemption challengehighlights the fact that one of the salient political considerations that led to the Code's current approach to exemptions - that the $\$ 522(\mathrm{~d})$ exemptions were simply too debtor oriented - has largely abated. ${ }^{239}$ That approach, as will be recalled, ${ }^{240}$ represented a last-minute compromise in the run-up to the Bankruptcy Reform Act of 1978 between the House bill, which created a set

seeking behavior do facilitate new and more efficient modes of financing. Id. at 1275 . Ultimately, how. ever, they largely condemn the practice as adding new costs associated with, inter alia, attempting to influence rule makers, adjusting to new rules, and generally from the uncertainties involved in an environment where priority rules are continually changing-and changing in potentially non-uniform ways, id. at $1272-78$.

${ }^{236}$ This is the criticism generally of the narrow, "proceduralist" view of bankruptcy. See, e.g., Vern Countryman, The Concept of a Voidable Preference in Bankruptcy, 38 VAND. L. ReV. 713, 827 (1985). Professor Countryman, in discussing Jackson's creditors" bargain model, opined that it assumes that "every creditor-apparently including asbestos victims and other tort claimants ...-will have full information and competent legal advice in dealing with the debtor. They assume further that every creditor will make the same assumptions they do and bring to bear their same highly skilled free market economic analysis

"Id. at 827. The adherents of the more expansive "practicalist" account that regards the bankruptcy system as advancing independent and unique substantive goals, separate and apart from state commercial law, is most closely associated with the work of Professor (now Senator) Warren. See Elizabeth Warren, Bankruptcy Policy, 54 U. CHr. L. Rev. 775 (1987). The terms "proceduralist" and "practicalist" come from Adam J. Levitin, Toward a Federal Common Law of Bankruptcy: Judicial Lawmaking in a Statutory Regime, 80 AM. BANKR. LJ. 1, 4.5 (2006). The two views about the scope and content of bankruptcy purposes and policies are also reviewed in Lawrence Ponoroff \& F. Stephen Knippenberg, The Implied Good Faith Filing Requirement: Sentinel of an Evolving Bankruptcy Policy, 85 Nw. U. L. Rev. 919, 948-955 (1992) (utilizing the rubric of collectivist vs. traditionalist thought).

${ }^{237}$ See supra notes 271.272 and accompanying text.

${ }^{238}$ The two positions as to whether or not Congress has delegated authority to the states (separate and apart from the issue of the permissibility of such a delegation) by means of the opt-out can be found in, respectively, the majority and dissenting opinions in Sticka v. Applebaum (In re Applebaum), 422 B.R. 684 (B.A.P. 9th Cir. 2009).

${ }^{239}$ See infra text accompanying notes 247.250 .

${ }^{240}$ See supra note 21 . 
of federal exemptions and gave the debtor the right to choose between those exemptions and the debtor's applicable state exemptions, ${ }^{241}$ and the Senate Bill, which continued the practice under the former Act of simply incorporat. ing the debtor's state and nonbankruptcy federal exemptions. ${ }^{242}$ Many com. mentators regard the solution ultimately adopted - the House approach but with the ability of the states to take away that choice for their residents-as ill-considered. ${ }^{243}$ Others see in it a calculated attempt to appease those interests that felt strongly about state control, but otherwise allow for federal control, as the Commission had urged in its 1973 Report, ${ }^{244}$ where sentiment was less intense. ${ }^{245}$ All agree that the compromise was decidedly a political one. ${ }^{246}$

At the time that bankruptcy reform was being debated in the 1970s, state exemption laws, with certain notable exceptions, were largely antiquated and out-of date both with respect to the type of property declared to be exempt and as to the value of exempt property entitled to protection. ${ }^{247}$

${ }^{241}$ H.R. 8200 , 95th Cong. $\$ 522$ (1978). This structure was proposed originally in a bill advanced by the National Conference of Bankruptcy Judges. See H.R. 32, 94th Cong. (1975); S. 235, 94th Cong (1975). Under this proposal the federal exemptions would serve, effectively, as a floor. The House Report on the bill expressed the sentiment:

Though exemption laws have been considered within the province of State law under the current Bankruptcy Act, H.R. 8200 adopts the position that there is a Federal interest in seeing that a debtor that goes through bankruptcy comes out with adequate possessions to begin his fresh start. Recognizing, however, that circumstances do vary in different parts of the country, the bill permits the states to set exemption levels appropriate to the locale and allows debtors to choose between the State exemptions and the Federal exemptions provided in the bill.

H.R. REP. No. 95.595, at 126 (1977), reprinted in 1978 U.S.C.C.A.N. 5963, 6087.

${ }^{242} \mathrm{~S}$. 2266, 95th Cong. $\$ 522$ (1978). In the final a compromise, the dollar amounts in the House Bill were reduced, the Senate's version of $\S 522(f)(2)$ ultimately was adopted, along with the opt-out provisions of $\$ 522(\mathrm{~b})(1)$. See Brown, supra note 18, at 160 . See generally Michael Terry Hertz, Bankruptcy Code Exemptions: Notes on the Effect of State Law, 54 AM. BANkR. L.J. 339 (1980); Vukowich, supra note 45 .

${ }^{243}$ Brown, supra note 18; Countryman, supra note 12; Vern Countryman, Bankruptcy and the Individ. ual Debtor-And a Modest Proposal to Retum to the Seventeenth Century, 32 CATH. U. L. REv. 809, $819-20$ (1983) (vehemently criticizing the opt-out in $\$ 522$ (b)); Haines, supra note 19; Hertz, supra note 242, at 339 (calling the opt-out compromise "unfortunate"); Richard E. Mendales, Rethinking Exemptions in Bankruptcy, 40 B.C. L. REV. 851, 851 (1999) (calling the current system "far too complex, inconsistent, inequitable, burdensome . . and rife with moral hazard); Ponoroff, supra note 18.

${ }^{244}$ Supra note 15 and accompanying text.

${ }^{245}$ See Eric A. Posner, The Political Economy of the Bankruptcy Reform Act of 1978, 96 MICH. L. REV. $47,107-08$ (1997) (opining that, as a result of the opt-out, "the federal government picked up some power without offending those with the most to lose.).

${ }^{246}$ See. e.g., SUllivan, ET AL., supra note 19, at 28 (observing that with the opt-out "[c]ongress once again sidestepped a sticky political issue by leaving the decision to the state legislatures."); Lawrence Ponoroff \& F. Stephen Knippenberg, Debtors Who Convert Their Assets on the Eve of Bankruptcy: Villains or Victims of the Fresh Start? 70 N.Y.U. L. REv. 235, 253 n.76 (1995) (discussing authorities that describe $\S 522(\mathrm{~b})(1)$ as a political compromise).

${ }^{247}$ See Lowell P. Bottrell, Comfortable Beds, A Church Pew, A Cemetery Lot, One Hog, One Pig. Six 
Spurred to a considerable extent by the Bankruptcy Reform Act of 1978, many states subsequently modernized and expanded the scope of their general exemptions, sometimes in connection with the enactment of opt-out legislation and sometime independently. ${ }^{248}$ That trend has continued to the present, including, more recently, the proliferation of bankruptcy-specific exemptions schemes. ${ }^{249}$ In an ironic sort of way, one of the effects of this gradual conflation in the scope and content of state and federal bankruptcy exemptions has been to blunt many of the arguments that historically had been mustered in opposition to mandatory federal exemptions in bankruptcy and that resulted in the Code's opt-out mechanism in the first place. ${ }^{250}$

To begin with, as Professor Eric Posner pointed out in 1997, the issue was never one purely of federalism, as it was often postured, 251 but rather also a question of control over the "content" of exemption laws. ${ }^{252}$ Posner

Sheep, One Cow, a Yolk of Oxen or a Horse, and Your Notary Seal: Some Thoughts About Exemptions, 72 N.D. L. REV. 83, 91-92 (1996) (noting the lack of much rhyme and reason to many state exemption schemes); Countryman, supra note 12, at 681-83 (expressing the view that state legislatures really did not care much about exemptions). See also Raymond C. Marier, Bankruptcy Exemptions: A Full Circle Back to the Act of 1800?, 53 CorNeLl L. REV. 663, 663.65 (1968) (arguing that reliance on state exemptions is confusing and inadequate); Note, Bankruptcy Exemptions: Critique E S Suggestions, 68 Y ALE L.J. 1459, 1463 (1959) (describing state exemption statutes at the time as having been "fashioned on an anvil of nineteenth century economics and politics.").

${ }^{248}$ See, e.g., Brown, supra note 18 , at 163 (discussing the frequency of states' amendments of their exemptions since 1979); Haines, supra note 19, at 14 n. 50 (cataloguing the states that, in connection with passing opt-out legislation, adopted extensive revisions to their general state exemptions; largely revisions that expanded these exemptions); Mendales, supra note 243, at $867 \mathrm{n} .135$ ("Several states have modern. ized their exemption laws in recent years, in part responding to the 1970 Commission's report and the adoption of the Bankruptcy Code in 1978.") (citing William J. Woodward, Jr., Exemptions, Opting Out, and Bankruptcy Reform, 43 OHIO ST. L.J. 335, 344-45 (1982)). See also Dionne v. Harless (In re Harless), 187 B.R. 719, 729 (Bankr. N.D. Ala. 1995) ("Many states have updated their exemptions in recent years to shelter retirement assets from debt collection."). Cf. In re Vasko, 6 B.R. 317, 322.23 (Bankr. N.D. Ohio 1980) (noting that in order to enhance a fresh start for debtors, Congress, in enacting to Code, not only included a liberal exemption scheme, but also encouraged the states to update and liberalize their own exemption laws).

${ }^{249}$ The BAP in Schafer identified nine states, including Michigan, that have enacted exemptions that only apply in Bankruptcy. Richardson v. Schafer (In re Schafer), 455 B.R. 590,599 n.10 (B.A.P. 6th Cir. 2011), rev'd, 689 F.3d 601 (6th Cir. 2012), cert. denied, 133 S. Ct. 1244 (2013). Clearly, however, the number is under-inclusive as it excludes, among others, Arkansas and Kansas. See Ark. CODE ANN. $\$ 16$ 66-218 (2012); supra note 78 (detailing a comparable approach taken in New York). The inexactitude of the count likely is the product of the diversity in types of bankruptcy-only exemption statutes as discussed supra Part II.

${ }^{250}$ See infra text accompanying notes $271-273$.

${ }^{25}$ See 124 Cong Rec. 17,406 (daily ed. Oct. 6, 1978) (statement of Sen. Wallop) (heralding the Bankruptcy Reform Act's rejection of mandatory federal exemptions as a "victory for states' rights" and the ability of the states to know best and provide for the needs of their citizens). See also Kennedy, supra note 17 , at 452 (stating in relation to the idea of returning to the listing in the federal bankruptcy law of specific items of property to be exempt in bankruptcy cases, "[r]eservations may thus be legitimately entertained regarding the wisdom as well as the political feasibility of a uniform law of exemptions in bankruptcy.").

${ }^{252}$ Posner, supra note 245 , at $95-96$. 
suggested that the ability to dictate exemption policy was generally more valuable to state and local politicians than to federal politicians, and hence the decision to allow the states to preclude their debtors from claiming the $\S 522(\mathrm{~d})$ exemptions. ${ }^{253}$ For instance, he theorized that the differing approaches toward exemptions in the House and Senate bills prior to enactment of the Bankruptcy Reform Act of 1978 was explicable in terms of the relative difference in the locus of political power between representatives and senators, as well as the disproportionate impact of less populous, rural states in the Senate as compared with the House. ${ }^{254}$ Posner described the opt-out compromise, therefore, as "ingeniously" retaining federal control over exemption policy in states where interest in the subject was low, but preserving the prerogative of the states in those situations (which turned out apparently to be most) where the state had a strong interest in controlling exemption levels - whether in order to compel its debtors to use lower value state ex. emptions, or permit its debtors the ability to use exemptions higher, than the federal bankruptcy exemptions.

While this solution may have been "ingenious" from the perspective of political expediency, it was dreadful policy. A uniform bankruptcy law may not require that all debtors be treated the same, but it should be construed to assure that the bankruptcy law operates in a uniform fashion insofar as imple. menting essential bankruptcy policy is concerned. ${ }^{255}$ A law which deprives some debtors of minimally adequate exemptions, while placing nearly all the assets of other debtors beyond the reach of the trustee, fails this standard of uniformity miserably. The situation has been made all the more distressing given the weight of more recent authority rejecting constitutional challenges to bankruptcy-specific exemptions, thus opening the door further to the kind of jumble of individual state practices that accounted for the decision to "federalize" bankruptcy law in the first place. ${ }^{256}$ What these judicial decisions overlook is that the original legislative decision by Congress to incorporate state law of general applicability in this area, however unwise, is something quite different from approving a delegation to the state legislatures of the

\footnotetext{
${ }^{253} \mathrm{Id}$. at 101.04 (noting, for instance, that insurance companies had done well at the state level, since high exemptions for insurance would cause debtors considering bankruptcy to sell nonexempt assets and purchase exempt policies).

${ }^{254} \mathrm{Id}$. at 106-07. Thus, the Senate bill reflected greater deference to the states in the matter of exemption policy.

${ }^{255}$ Int'l Shoe Co. v. Pinkus, 278 U.S. 261, 263.65 (1928) (holding that a state is without power to enforce any law governing bankruptcies or that interfere with or complement the national bankruptcy law). See also supra text accompanying notes 180-182.

${ }^{256}$ See Sticka v. Applebaum (In re Applebaum), 422 B.R. 684, 697 (B.A.P. 9th Cir. 2009) (Markell, J., dissenting) (describing the consequences of the majority's approach as encouraging a "patchwork-quilt methodology" consisting of hundreds of different exemption schemes that the bench and bar will have to contend with). See also supra notes $128,133-135$ and accompanying text.
} 
ability, in spite of Congress's preeminent designated role in the area, to decree outcomes that apply only in bankruptcy. ${ }^{257}$ To do so makes no more sense in terms of preserving the integrity of a national, uniform bankruptcy law than allowing states to pass legislation insulating its residents from recovery by the trustee for certain kinds of preferential transfers, which surely would never be countenanced, ${ }^{258}$ but the weight of recent authority has approved just that result in the case of exemption policy.

\section{B. Federal Uniformity Revisited}

In its own ham-handed fashion, BAPCPA has begun to unwind state control over exemptions in the case of excessively generous exemptions, though the law did nothing about ensuring an adequate minimum level of exemptions, ${ }^{259}$ except in situations where the complex requirements of $\$ 522(\mathrm{~b})(3)(\mathrm{A})$ renders the debtor ineligible for any exemptions. ${ }^{260}$ The concern, however, for debtors who manipulate their locations or circumstances to enjoy larger exemptions than those to which they might otherwise be entitled reflects a recognition that, regardless of the exemptions from execution that such debtor might enjoy under state law, certain uniform, national controls must be imposed in the interests of federal bankruptcy policy and the differing interests and concerns at stake in a bankruptcy case as contrasted with state law judgment execution. ${ }^{261}$

Similarly, as a matter of constitutional analysis, there seems to be agree-

${ }^{257}$ See In re Cross, 255 B.R. 25, 34 (Bankr. N.D. Ind. 2000) (observing that the recognition of statecreated non-bankruptcy entitlements is very different than allowing the states to actually create entitlements in bankruptcy). See also In re Wallace, 347 B.R. 626, 631 (Bankr. E.D. Mich. 2006) (“[I]n giving states the ability to opt out of the federal bankruptcy exemptions Congress did not give them the authority to create bankruptcy exemptions. Instead, what the opt-out represents is a Congressional willingness to recognize the generally available exemptions that states have created for their own purposes in bankruptcy proceedings." (quoting Cross, 255 B.R. at 34 n.5)), abrogated by Richardson v. Schafer (In re Schafer), 689 F.3d 601 (6th Cir. 2012), cert. denied, 133 S. Ct. 1244 (2013).

${ }^{258}$ See supra note 171 .

${ }^{259}$ See supra notes $28-31$. In addition, BAPCPA expanded the categories of property deemed exempt by $\$ 522(b)(3)$ to include most forms of tax-exempt retirement assets, irrespective of their status under state law. See supra note 20.

${ }^{260}$ See In re West, 352 B.R. 905 (Bankr. M.D. Fla. 2006) (holding that, under these circumstances (where a state's exemptions apply by virtue of $\$ 522(\mathrm{~b})(3)(\mathrm{A})$ but provide that such exemptions only extend to residents of that state), the debtor is entitled to the federal exemptions in $\$ 522(d)$ notwithstanding the fact that, as of the date of filing, the debtor resided in an opt-out jurisdiction). Cf. In re Garrett, 435 B.R. 434, 444.46 (Bankr. S.D. Tex. 2010) (distinguishing West and comparable authority on the ground that these decisions considered the extra-territoriality of the states' exemption law, but not their opt-out legislation that similarly only applied to residents of the states).

${ }^{261}$ Ironically, the concerns prompting additional restrictions on a debtor's ability to claim state law exemptions imposed by BAPCPA are precisely the same as the concerns that caused the NBRC to call for a much broader, and a much more equitable, reform of exemption policy in bankruptcy. See supra notes 25.26 and accompanying text. They are also an important part of the reason that the Framers saw fit to repose the bankruptcy power in the national government. See supra text accompanying notes 128-138. 
ment, even among the courts that recognize the validity of state-enacted bankruptcy exemptions, that there are limits on enforceability, ${ }^{262}$ even if those limits are difficult to identify and apply in any given case. ${ }^{263}$ This circumscription was evident as early as the In re Vasko decision, ${ }^{264}$ one of the first cases involving a challenge to bankruptcy-only state exemptions. The court in that decision upheld the constitutionality of a provision of Ohio law that, at the time, exempted the debtor's interest in certain property, such as deposit accounts, as well as any property, in each case not to exceed $\$ 400$, but only in a bankruptcy proceeding. ${ }^{265}$ As part of its rationale, the court explained that, in adopting the "opt-out" in $\S 522(\mathrm{~b})(1)$, Congress' hope was "that the states would update and revamp the existing laws, bringing them closer into line with the federal exemptions." ${ }^{266}$ Because this is exactly what Ohio did, according to the court, the Ohio law in question could not be considered to "interfere with, impede, or conflict with the Congressional policy of giving debtors a fresh start. ${ }^{267}$ It seems reasonable to infer from this statement, as one might also infer from Judge Cole's statement thirty years later in Schafer, ${ }^{268}$ that a state-enacted exemption statute that was less generous to the state's residents than its general exemption laws would not pass muster.

As discussed earlier, admission of this apparent boundary, implying some regulation on the content of bankruptcy-specific state exemptions, was likely seen as necessary to avoid constitutional concerns, although it is not at all clear that in fact it does elide those apprehensions. ${ }^{269}$ In addition, however, it also represents a further constraint on the applicability of state exemptions in

${ }^{262}$ See supra text accompanying note 189

${ }^{263}$ See supra text accompanying notes 193-196.

${ }^{264} 6$ B.R. 317 (Bankr. N.D. Ohio 1980).

${ }^{265}$ OHIo REV. CODE ANN. $\$ 2329.66(A)(4)(a),(A)(17)(1980)$. The current version of the exemption, Ohio Rev. Code ANN. $\$ 2326.66(\mathrm{~A})(18)$, simply exempts a person's interest in any property not to exceed $\$ 1,150$, but only in a bankruptcy proceeding.

${ }^{266}$ Vasko, 6 B.R. at 322 .

${ }^{267} \mathrm{Id}$. at 322.23 (suggesting as well that the Ohio legislature had "complied with the intent of Congress.").

${ }^{268}$ Richardson v. Schafer (In re Schafer), 689 F.3d 601, 616 (6th Cir. 2012), cert. denied, 133 S. Ct. 1244 (2013).

${ }^{269}$ See supra note 129; supra text accompanying note 194 . The fact that a state law happens (or at least appears) to coincide with one of the policies underlying the federal bankruptcy law does not itself confer authority on the state to pass that law in the first place, and, such authority cannot exist (nor arguably, under the current language of $\S 522(\mathrm{~b})$, did Congress seek to bestow it) in the face of Congress's exclusive responsibility for enacting bankruptcy laws. Despite its later protestations to the contrary in Schafer, this is precisely the point made by the Sixth Circuit in Hood $v$. Tennessee Student Assistance Corp., 319 F.3d 755, 765 (6th Cir. 2003), affd on other grounds, 541 U.S. 440 (2004), wherein the court noted that the Sturges $v$. Crowninshield, 17 U.S. (4 Wheat.) 122, (1819), non-exclusivity interpretation of the Bankruptcy Clause was "based less on the original understanding of the Convention than on the necessity of having some system in place when Congress could not [or did not] enact bankruptcy legislation." (emphasis in original). 
bankruptcy (or the delegation of control over the subject to the states), calling into question, separate and apart from the constitutional issues, the wisdom and, more importantly, the political necessity of continuing the recognition of any state exemption laws in bankruptcy cases. The most common bases for objection to the 1973 recommendation of the Bankruptcy Commission on exemptions were that adoption of uniform federal exemptions would intrude upon state's rights, produce a sharp increase in bankruptcy filings both voluntary and involuntary, unfairly dash creditor reliance on state law exemptions, and cabin off too much of the debtor's property from liquida. tion and distribution to creditors in bankruptcy. 270

And yet, the continued increase in the number of states adopting bankruptcy-only exemption schemas that actually offer more generous exemptions to their debtors in bankruptcy cases, a quarter-century of experience demonstrating the seeming insignificance of exemptions in precipitating bankruptcy filings, ${ }^{271}$ and the fact that, in several instances, the state-enacted bankruptcy-only exemption lists closely mirror the $\$ 522(\mathrm{~d})$ exemptions, ${ }^{272}$ all point to the fact that the opposition, or bases for opposition, that existed in the 1970 s to mandatory federal bankruptcy exemptions has abated considerably. Concomitantly, the modernization of many state exemption laws since $1978{ }^{273}$ would also seem to have tempered the passions that made state versus federal control over the area such a contentious affair in the past.

Along similar lines, contemporary consumer credit decisions have largely come to be based either on individual analysis of the debtor's ability to repay (facilitated by credit scoring), particularly in the case of larger extensions of credit, such as automobiles and home equity loans, ${ }^{274}$ and actuarial analysis of the aggregate rate and likelihood of default in the case of smaller unsecured

\footnotetext{
${ }^{270}$ See generally Ponoroff, supra note 18 at, 236-46.

${ }^{271}$ See Brown, supra note 18, at 186 (noting that if the purpose of the opt-out was to act as a deterrent to bankruptcy, there is little evidence that it has worked); SULLIVAN ET AL., supra note 19, at $240-42$ (finding that variations on filing rates within states (where state exemption laws were uniform) were greater than variations among states where exemption laws differed substantially); William $\mathbf{J}$. Woodward, Jr. \& Richard S. Woodward, Exemptions as an Incentive to Voluntary Bankruptcy: An Empirical Study, 57 AM. BANKR. L.J. 53, 66.70 (1983) (concluding that altering federal exemptions probably has no significant effect on bankruptcy filing rates). Cf. Susan Block-Lieb \& Edward J. Janger, The Myth of the Rational Borrower: Rationality, Behavioralism, and the Misguided "Reform" of Bankruptcy Law, 84 TEX. L. REV. $1481,1523.25$ (2006) (concluding that the evidence thus far as to the correlation between exemption law and personal filing rates have produced conflicting and confusing results).

${ }^{272}$ See supra text accompanying notes 67,76 .

${ }^{273}$ See supra note 248.

${ }^{274}$ Liran Einav, Mark Jenkins \& Jonathan Levin, The Impact of Credit Scoring on Consumer Lending, 44 RAND J. Of ECON. 249 (2013) (discussing the positive impact of automated credit scoring of the profitability of consumer lending), available at http://www.stanfordedu/ leinav/pubs/RAND2013.pdf David A. Lander, "It 'Is' the Best of Times, It 'Is' the Worst of Times": A Short Essay on Consumer Bankruptcy After the Revolution, 78 AM. BANKR. L.J. 201, 205 (2004) (attributing the increased profitability of higher risk consumer lending to lender consolidation and improved credit-scoring techniques).
} 
extensions of revolving credit, such as most credit card transaction arrangements. ${ }^{275}$ In other words, actual creditor reliance on state exemption levels, an argument previously raised in opposition to federalizing the law in this area, 276 is virtually non-existent, except perhaps to the extent that the abuse of unlimited exemptions in a few states produces higher overall costs of credit. Furthermore, regulatory changes in the banking and finance arena have made consumer credit a far less local affair, ${ }^{277}$ and the less local the relationship the less reliance on state exemptions as a source of repayment.

In short, the growing obsolescence of the reasons why states wanted to exclude their debtors from access to federal exemptions, ${ }^{278}$ coupled with BAPCPA's both limitation on and expansion of state exemptions when required or permitted, all point to the desirability of solving the issue of the constitutionality of bankruptcy-specific exemptions by making the point moot. In other words, the benefits to be derived from mandatory uniform federal exemptions in bankruptcy that have caused so many objective commentators to call for their adoption ${ }^{279}$ remain no less robust than they ever

${ }^{275}$ See Tom Brown \& Lacey Plache, Paying with Plastic: Maybe Not So Crazy, 73 U. CHI. L. ReV. 63, $73-74$ (2006) (discussing how technological changes, including the Internet, have transformed consumer lending); Sousa, supra note 1, at 612 ("[S]ophisticated consumer lenders have spreadsheets and actuarial tables backed by complex financial models that predict their rate of loss and expected profit margins based upon their portfolio of borrowers. In other words, the prudent lender has already calculated average expected losses and profits ex ante, before ever transacting with a potential customer. So if a creditor lends and the debtor later fails to repay, the creditor is best positioned to bear the consequences of default."); Sullivan, ET AL., supra note 19, at 285-87 (describing actuarial lending and distinguishing it from the process typically involved in commercial lending). See also Ponoroff, supra note 18, at $244 \mathrm{n} .113$ (collecting authorities demonstrating the increasingly less local character of the banking and financial services industries); Bernard Shull \& Gerald A. Hanweck, Bank Merger Policy: Proposals for Change, 119 BANKING L.J. 214 (2002) (discussing the consolidation of occurring since the 1980's in the commercial banking arena as a result of merger activity).

${ }^{276}$ See, e.g., William T. Vukowich, The Bankruptcy Commission's Proposal Regarding Bankrupts' Ex. emption Rights, 63 CALIF. L. REV. 1439, 1444 (1975) (suggesting creditor reliance on local exemptions as a justification supporting $\$ 6$ of the $1898 \mathrm{Act}$ ).

${ }^{277}$ The days of high-touch, local, personalized banking, such as George Bailey's neighbors received from Bailey Building \& Loan, IT's A WONDERFUL LifE (Liberty Films, Inc. 1946), are increasingly becoming a vestigial remnant of days gone by. Rob Cox, So Long, Bailey Building $\mathcal{E}^{2}$ Loan, THE New YORK TIMES (Dec. 22, 2010), http://www.nytimes.com/2010/12/23/business/23views.html?_r=0 (discussing the disproportionately more burdensome impact of regulatory requirements on locally owned community banks and finance companies). See also Arthur E. Wilmarth, Jr., The Dark Side of Universal Banking: Financial Conglomerates and the Origins of the Subprime Financial Crisis, 41 CoNN L. REv. 963 (2009) (analyzing the effects of mass marketing, automated processing, credit scoring, and securitization on consumer lending business).

${ }^{278}$ As detailed, these included concerns over the excessive generosity of the Code's exemptions, an increase in bankruptcy filings to take advantage of the exemptions, dashed creditor reliance, and that the Code ignores the essentially local character of exemptions laws.

${ }^{279}$ See authorities cited supra note 241. See also Vukowich, supra note 276 , at 1441-46 (extolling the desirability of the Commission's proposal for uniform federal exemptions in bankruptcy); Note, Bankruptcy Exemptions: A Full Circle Back to the Act of 1800?, 53 Cornell L. Rev. 663, 664-65, 668 (1968) (ad. dressing the inadequacy of use of state law exemptions in bankruptcy). 
were, but the reasons for resistance (other than a purely ideological attachment to the notion of states' rights ${ }^{280}$ ) have been blunted considerably.

It should finally be noted that states might continue to have some role to play even under a system incorporating most of the features of mandatory uniform federal exemptions, albeit to a far lesser extent than is currently the case. That is to say, there are certain aspects of exemption policy that continue to have some local flavor by virtue of regional differences in cost of living and the relative importance of different types of property in different parts of the country. ${ }^{281}$ Of course, in some instances, intrastate differences in these areas can be as significant as interstate differences, and, in any event, there are certainly ways to deal with both of these issues in a purely federal system. ${ }^{282}$ Nevertheless, the point remains that this could be an area where there is some flexibility for a form of "reverse" cooperative federalism to operate. While the term cooperative federalism is typically used to describe programs in which the states are delegated primary responsibility for the administration of important federal initiatives, commonly in the areas of labor, the environment, and healthcare, ${ }^{283}$ the idea of shared responsibility to solve a common problem might apply equally to the dilemma associated with assuring that federal bankruptcy policy at the national level is implemented in a manner that accounts for local differences in standards of living and the necessity or desirability of owning particular categories of property in different parts of the country.

Local variations are likely to be most significant in the case of the homestead exemption since it is typically the largest dollar value exemption and real estate is subject to greater regional differentiation in value than virtually any form of personal property. Thus, as recommended by the NBRC, ${ }^{284}$ state-determined homestead exemptions might continue to control in bank-

\footnotetext{
${ }^{280}$ On that score, see Edward L. Rubin \& Malcom Feeley, Federalism: Some Notes on a National Neurosis, 41 U.C.L.A. L. REv. 903, 908.09 (1994) (dismissing federalism as the anachronistic residue of eighteenth century British colonial administration).

${ }^{281}$ For example, no national listing of types or categories of exempt property is likely to include "one snowblower" and "one large crawfish boiling pot," but each is essential to, respectively, residents of northern Minnesota and southern Louisiana. See generally Ponoroff, supra note 18, at 238.

${ }^{282} I d$. at 238-39, 246 (pointing out that use of a single cash denominated limit for personal property would account for the differing needs of debtors in different states, and adjustment of the exempt dollar value limit by regional CPI would address differences in cost of living). Others have made these suggestion as well, see id. at $238 \mathrm{n} .81$, and they also formed the basis of Judge Brown's and my recommendations to the NBRC, and that the NBRC largely adopted in its 1997 Report. See supra notes 25.27 and accompanying text.

${ }^{283}$ See generally Ronald J. Krotoszynski, Cooperative Federalism, the New Formalism, and the Separation of Powers Revisited: Free Enterprise Fund and the Problem of Presidential Oversight of State-Government Officers Enforcing Federal Laws, 61 DuKE L.J. 1599, 1629-35 (2012) (providing an overview of three current cooperative federalism programs and reviewing elements common to such programs generally).

${ }^{284}$ See supra notes $25 \cdot 27,282$ and accompanying text.
} 
ruptcy cases, but subject to a federal floor as well as ceiling, and with neither being time limited as is currently the case. ${ }^{285}$ Likewise, the states might be given authority to designate, subject to a dollar limitation, one or two items of non-real property that residents of that state could exempt in a bankruptcy case in addition to the federally-designated categories of exempt property or, preferably, in addition to the lump-sum cash allowance for personal property exemptions provided for by the Code. ${ }^{286}$

\section{CONCLUSION}

The constitutionality of state-promulgated bankruptcy exemptions remains in doubt. The doctrine of geographical uniformity may allow for debtors from different jurisdictions to experience different outcomes in bankruptcy if that is Congress's will. That, however, is a far cry from congressional acquiescence in state intrusion into the constitutionally enshrined policy for national control and uniformity in the establishment of bankruptcy laws. In other words, Article I's conferring on Congress the power to promulgate a uniform national law does not preclude enactment of a rule that leaves some aspect upon which the operation of that otherwise uniform rule depends to state or local law. It does, however, mean that Congress cannot constitutionally delegate back to the states the power to make a law over a subject that the Constitution entrusts to the federal government. Thus, Congress may decide to allow a state law, adopted for general purposes, to apply in bankruptcy, or seemingly even give the states the authority to make the decision, as with the opt-out, that the state law shall govern some aspect of the bankruptcy proceeding. State-enacted bankruptcy-only exemptions schemas, however, exceed those limitations inasmuch as they entail directing bankruptcy outcomes separate and distinct from treatment of the same issues under general state law.

Aside from the limitations imposed by the Bankruptcy Clause, there is also the question of preemption. It seems universally to be agreed that the Supremacy Clause would prohibit the enforceability of state legislation that undermines national policy. ${ }^{287}$ Yet, once we allow the states, rather than Congress, to determine what law applies in, and only in, a federal bankruptcy case, we open the door to precisely that result inasmuch as the impact of a state statute on national bankruptcy policy is neither consistent nor constant

\footnotetext{
${ }^{285}$ The limitations that BAPCPA placed on the homestead exemption lapse after a certain period of time. See supra note 31 and accompanying text. Under the NBRC proposal, both the ceiling and the floor would be permanent.

${ }^{286}$ Bottrell, supra note $247,91-92,96-97$ (noting that most states have a "hodge podge" exemption scheme and suggesting the wiser approach would be to have a single exemption with a dollar limitation that the debtor can use as he or she best sees fit). See also supra note 282.

${ }^{287} \mathrm{See}$ supra notes 144,175 and accompanying text.
} 
from case to case nor over time. Therefore, the phenomenon, if permitted, poses the very real, but difficult to detect, threat of impermissible interference by the states with the objectives of the federal bankruptcy law. Correlatively, it could also create potential concerns under the Contracts Clause should a state become too generous in its bankruptcy-only exemption scheme, ${ }^{288}$ although Congress seems at least to have awakened and responded to that possibility in the 2005 amendments. ${ }^{289}$

The reasoning of the decisions rejecting constitutional attacks on bank. ruptcy-specific exemption schemes merits reconsideration. It is not at all clear that Congress has, in fact, delegated this authority to the states in the first place, and, in any case, $\$ 522$ (b) ought not be construed so as to create a constitutional issue. ${ }^{290}$ Therefore, state-enacted bankruptcy-only statutes should be struck as violative of both the Bankruptcy Clause and the Supremacy Clause of the Constitution. The states are certainly free to resurrect those exemptions, so long as Congress maintains the opt-out, by making them available generally. If, however, that option is politically unpalatable, whether to local creditors or other intrastate interests, ${ }^{291}$ then that is where things must stand.

There is, however, a more expedient and sensible alternative to striking each of these laws, and an alternative that the very existence of these laws implies is timely. That is, of course, to revisit the recommendation from two blue ribbon commissions, and virtually every scholar to comment on the subject, ${ }^{292}$ urging restoration of the regime under the first two federal bank ruptcy laws of national legislative control over bankruptcy exemptions. ${ }^{293}$

${ }^{288}$ See supra note 138.

${ }^{289}$ See supra text accompanying notes $30-31$.

${ }^{290}$ This is precisely the approach recommended by Judge Rhodes in In re Reinhart. 460 B.R. 466,469 (Bankr. E.D. Mich. 2011) (urging that $§ 522$ (b) should be construed so as to avoid a serious question as to its constitutionality), abrogated by Richardson v. Schafer (In re Schafer), 689 F.3d 601 (6th Cir. 2012), cert. denied, 133 S. Ct. 1244 (2013).

${ }^{291}$ See William T. Plumb, Jr., The Recommendations of the Commission on the Bankruptcy LawsExempt and Immune Property, 61 VA. L. REV. 1, 152 (1975). (opposing federalization of bankruptcy exemptions, but acknowledging that that convenience to national creditors might be the only positive gain from adoption of national exemptions over varied rules of state law). See also supra note 83 (discussing the fact that permitting states to enact bankruptcy exemptions opens the door to this type of discrimination in favor of local creditors in contravention of bankruptcy equality policy, and may even be the explanation for why states have limited their exemptions reforms to the bankruptcy setting).

${ }^{292}$ See authorities cited supra notes 243,279 . There are two notable commentators who have taken contrary views: Professors Kennedy and Plumb. See Kennedy, supra note 17, at 446-53 (expressing concern over strategic behavior and creditor reliance on state exemption levels); Plumb, supra note 291, at 152 (inquiring whether there really is "any federal interest in seeing that the same properties are exempt from creditors in Kansas as in New York, that Virginia's exemptions are the same as California's?"). Though it will be recalled that Professor Kennedy would later become the Executive Director of the Commission, formed in 1970, that eventually recommended uniform federal exemptions. See supra note 17

${ }^{293}$ See supra note 48 and accompanying text. 
The case in favor of uniform federal bankruptcy exemptions, other than on the basis of constitutional mandate, is well known. The scholarly criticism of the former Bankruptcy Act's approach to exemptions and the arguments in favor of federalizing the subject remain no less valid today than when they were first presented, but the complexion of the argument has changed in certain respects due both to doctrinal changes and changes in consumer credit practices. To some extent, the concerns that prompted the call for uniformity have abated, 294 although certainly not to anywhere near the point of elimination. Likewise, express creditor reliance on exemptions in connection with unsecured extensions of credit is far more the exception than the rule it may have been even thirty years ago. ${ }^{295}$ On the other side of the equation, the increase in the promulgation by the states of exemptions applicable only in bankruptcy, and generally more favorable than the state's general exemptions, represents both (1) new reason to eliminate incorporation of state exemptions laws and the opt-out, and (2) reason to imagine that what might not have been palatable in the years leading up to the Bankruptcy Reform Act of 1978 may now be politically acceptable.

Even if changes in lending practices and national consolidation in the financial services industry have made exemptions less important from the perspective of state policy, ${ }^{296}$ the same is not true with regard to the role exemptions play in ensuring accomplishment of core bankruptcy policies, such as the fresh start and the fair and equitable treatment of similarly positioned creditors. That is to say, while the purpose for exemptions under state and federal bankruptcy law seems at first blush to overlap considerably, there are critical differences, and differences that make continued reliance on state exemptions in bankruptcy imprudent. The inability of states under the Contract Clause to discharge existing obligations, 297 and the indifference of state collection law to the interests of creditors inter se, represent key points of discrepancy in the environments in which exemption laws are enacted and operate. That dces and should necessarily impact the content of those laws. Foremost, however, by definition, the states can only enact legislation with local and insular interests in mind; Congress alone can enact exemption legislation with the outlook of effectuating the broader national interest in debtor relief and creditors' rights.

\footnotetext{
${ }^{294}$ The wide disparity between most states' exemptions, still mired in nineteenth century approaches in the 1970s, and the federal exemptions, has been closed to some extent by the modernization over the past several decades in most state exemption schemas. See supra note 248.

${ }^{295}$ See supra text accompanying note 276 . Even in the 1970 s, the concern may have been overstated. See Vukowich, supra note 276, at 1444 (pointing out the increasingly mobile nature of American society had already made it imprudent for creditors to rely on the exemption laws of the debtor's state of resi. dence at the time the credit was extended).

${ }^{296}$ See supra notes 273.276 and accompanying text.

${ }^{297}$ See supra note 138.
} 
These differences have always supported the argument for federalizing exemptions in bankruptcy. The growing phenomenon of state-enacted bank. ruptcy legislation makes the case even stronger, both by weakening the traditional arguments in favor of state control over exemption policy and by increasing the harm to the national interest created by reliance on state law. The "opt-out compromise" in 1978 was a cop-out, but it never contemplated ceding back to the states the power to legislate particular features of and outcomes in bankruptcy cases. Such legislation would be violative of the uniformity requirement properly understood and preempted by Congress' supreme authority in the field. Congress may delegate to the states the right to avoid certain aspects of federal law as it relates to their citizens, but Congress may not delegate, and arguably has not delegated, to the states authority to establish key features of the federal bankruptcy law. Thus, at a minimum, bankruptcy-specific exemption laws should be struck as constitutionally infirm. The even better, and certainly more holistic solution, however, is to seize the opportunity to reverse the mistakes of history and politics that have plagued exemption policy in bankruptcy for over a hundred years by leaving the states a proper role only in those areas where concerns are decidedly local, and otherwise assure that core bankruptcy policy will be served, as intended by the Framers, on a national basis through the adoption of mandatory, and truly uniform, federal rules governing exemptions in bankruptcy cases. 